\title{
State business relations and the dynamics of job flows in Egypt and Turkey
}

\author{
Oznur Ozdamar $^{1} \cdot$ Eleftherios Giovanis $^{2}$ (D) $\cdot$ Sahizer Samuk $^{3}$
}

Received: 3 September 2019 / Revised: 10 September 2020 / Accepted: 15 September 2020 /

Published online: 21 October 2020

(c) The Author(s) 2020

\begin{abstract}
Long-standing challenges concerning unemployment and the role of government have been the dominant underlying themes in the countries of the Middle East and North Africa (MENA) region. Effective State-Business Relations (SBRs) comprise a set of highly responsive and public interactions between the state and the business sector. The aim of this study is to explore the dynamics of net job creation rates in Egypt and Turkey, and the role of the SBRs, including various firm characteristics. The analysis relies on firm-level data derived from the World Bank Enterprise Surveys over the period 2008-2013. We implement the weighted ordinary least squares (OLS). Furthermore, we apply an Instrumental Variables (IV) Approach and the Two-Stage Least Squares (2SLS) method for robustness check, to deal with the potential endogeneity issues coming from the self-reported statements and the possible degree of reverse causality between SBRs and the main outcomes of interest. Our findings suggest four major obstacles to SBRs, with constraints of access to finance and credit and political instability being the common major obstacles in the two countries explored. Corruption and lack of proper infrastructure in electricity in Egypt are found to be the next two main obstacles in SBRs, while tax rates and competition from the informal sector are identified as the other two main obstacles in Turkey. The results show that obstacles in SBRs contribute negatively to the net job creation. According to these findings, policy implications include the need to make SBRs operate more efficiently, investments on proper infrastructure and policies that minimize corruption and political instability.
\end{abstract}

Keywords Firm level data $\cdot$ Job creation $\cdot$ State-business relations

Oznur Ozdamar

oznurozdamar@gmail.com

Extended author information available on the last page of the article 


\section{Introduction}

Employment growth, job creation and destruction and firm productivity have been always at the centre of interest of the governments around the globe and especially in the Middle East and North Africa (MENA) region, after the great recession of 2007. The MENA region countries are characterized by strong cyclical fluctuations and have experienced significant economic and political changes, such as the Arab Spring. Given the persistently high unemployment levels in emerging and developing economies, there is an increasingly strong focus amongst the policy makers about job creation and productivity growth. Creation and destruction of jobs makes workers shift from one job to another and switch between employment and unemployment. While labor supply factors can be important, such as skills, working experience, education and health; yet, job reallocation is one of the main factors behind workers' relocation activity. Evidence for this can be economic stagnation in the transition and developing economies, which cannot be explained only by the labor supply-side factors.

The motivation of this study for focusing on the SBRs as an additional factor of economic performance, lies in the long-standing literature in political economy and political science providing evidence that effective SBRs and an efficient and trustworthy business and investment climate can enhance growth and economic performance (Doner and Schneider 2000; Fajnzylber et al. 2009; Hansen et al. 2009; Qureshi and Te Velde 2013). Therefore, the main motivation of this study is the ongoing interest of policy makers about the possible sources of job creation and destruction and the role of State-Business Relations (SBRs).

SBRs are relations between the private and public sector and are shaped by the way businesses and states interact (Leftwich 2009). Positive SBRs are collaborative institutional arrangements between states and businesses characterized by a good two-way information flow between these agents that enables transparency, reciprocity in their relations and conditions in which state intentions and commitments are considered to be trustworthy (Maxfield and Schneider 1997). Examples of effective SBRs include improved allocative efficiency of government spending on productive firms; allocation of funding that improves the supply and quality of public goods, such as transportation and electricity; policies that minimize political instability, corruption and competition from the informal sector. According to Sen and te Velde (2009) effective SBRs may affect the industrial development and firm growth by two opposite forces. First, overcoming market failures, such as the market alone may not be able to achieve the optimal allocation of resources, such as innovation, climate change and education. Second, the states may not be able to address market failures on their own, because they can be captured by elites, suffer from moral hazard problems or are unlikely to have perfect information (Hausmann and Rodrik 2003).

A large part of the literature thus, highlights the importance of policies in promoting development actively. An institutional framework for policies to function properly, one where the government and business can collaborate to reach a consensus on the best direction for the economy, is central to all strategies. The 
question is no longer whether the industrial policies-labor regulations and investments on infrastructure services, reduction of the resource misallocation due to political instability, corruption and bureaucracy - are important, but rather how to adapt these policies and analyze the institutional context in which effective policies are designed and enforced.

The aim of this study is to explore the impact of the SBRs on job flow rates in Egypt and Turkey employing data from the World Bank Enterprise Surveys over the period 2008-2013. The empirical analysis relies on a weighted ordinary least squares (OLS). However, due to potential endogeneity issues coming from the selfreported structure of the SBRs and the possible degree of reverse causality between SBRs and the main outcomes of interest, we apply the Two-Stage Least Squares (2SLS) method for robustness check. The results show that the four main obstacles in effective SBRs include access to finance and credit, political instability, high tax rates, corruption, competition from the informal sector and lack of proper infrastructure in electricity supply.

The findings suggest that the establishment of effective SBRs requires an adequate policy framework to support the development of the industry, employment and economic growth overall. Therefore, policy recommendations involve improvement on the building capacity to conduct meaningful and effective SBRs, settings that improve labor regulations encouraging the increase of employment, reforms that reduce corruption and remove uncertainty coming from political instability, and policies that maximize the inclusiveness of firms, especially start-ups and young firms, to finance and credit.

The organization of the paper is as follows. Section 2 presents earlier studies, while in Sect. 3 we describe the methodological framework and the data employed in the empirical analysis. In Sect. 4 we present the empirical results and in Sect. 5 we discuss the main concluding remarks.

\section{Literature review}

Effective SBRs are associated with the establishment of institutional environments that state provides higher quality of public goods, including effective public administration, reduction, if not elimination, of corruption and political instability, promotion of tax incentives and credits for young start-ups and high productive firms, and investments on reliable provision of infrastructure that is crucial for the production process and business performance, such as transportation network, internet, water and electricity supply. The majority of previous studies illustrate the importance of a trustworthy and effective collaboration between the state and businesses on economic growth and firm performance (Kormendi and Meguire 1985; Knack and Keefer 1995; Rodrik et al. 2004; Giovanis and Ozdamar 2018a, b). However, the countries of MENA region are also characterized by high levels of informality, which is the part of the economy that neither taxed nor regulated or monitored by the government and public authorities. The study by Elgin and Erturk (2019) presents a detailed and comprehensive literature review analysis about the determinants of informality and they found that apart from taxes and labor market indicators; 
institutional quality is one of the most important factors that may increase the intensity of informality in the economy. Institutional quality includes political instability, law enforcement, corruption and bureaucratic quality, which are explored in this study. At the macro level earlier studies found also a positive impact of the Information and Communication Technology (ICT) on Total Factor Productivity (TFP) growth. For instance, Hawash and Lang (2020) using panel data for 76 developing countries over the period 1991 to 2014 found that countries with relatively high intensity of ICT, experience an annual increase in the TFP growth by 0.1 to 0.3 percent compared with countries with modest investment in ICT. This indicates that infrastructure plays a major role on the firm performance and economic growth.

Following the macro-level evidence, numerous studies have explored the factors of firm performance, including employment growth, using micro-data level analyses. Earlier literature exploited administrative business-level data on employment dynamics and the job creation and destruction flows focusing mainly in the USA. One of the first studies is by Davis et al. (1993) who investigated US firms in the manufacturing sector during the period 1972 to 1988 . Their study shows that the most newly-created and newly-destroyed jobs are accounted by large firms and plants and the survival rates for the new and existing jobs are increased with the firm size. Furthermore, the authors found that smaller firms and plants exhibit higher gross job creation rates, but not higher net job rates. The seminal works by Dunne et al. (1989), Davis and Haltiwanger (1990, 1999) and Davis et al. (1998) found that job creation and destruction occur simultaneously and the job reallocation shows systematic patterns over the business cycle, which reallocation is defined as the sum of the absolute values of job creation and destruction. Various concluding remarks are derived from previous studies. Lotti et al. (2003) and Hijzen et al. (2010) found that the "Gibrat's Law" is violated (Gibrat 1931), since their results support a negative relationship between firm size and growth. However, Haltiwanger et al. (2013) found an insignificant relationship between size and growth when the regressions control for firm age. Bartelsman et al. (2019) using firm-level data from 10 European countries during the period 2002-2010 found that ICT and broadband usage are better predictors of productivity than product innovation, indicating that SBRs should focus on investments related to ICT and broadband services.

Another field of literature focuses on the cyclicality of employment by different types of firms. A number of studies found that the small firms respond more to monetary and financial shocks (Gertler and Gilchrist 1994; Sharpe 1994), while Moscarini and Postel-Vinay (2012) show that the employment in the large firms is more related to unemployment rates changes than in the small firms. Furthermore, according to Beck et al. (2005a) young and small firms contribute mostly to the new job creation. For instance, Decker et al. (2014) found that even though the rate of new entry and exit of firms has fallen during the period 1980-2011 in the USA, a large proportion of the net job creation was actually crated by the minority of the new firms that have succeeded and grew. Newborn firms can contribute significantly to innovation fostering and improved efficiency in the developing countries (Goedhuys and Sleuwaegen 2010).

Cravo et al. (2018) used a unique monthly linked employer-employee dataset to explore the cyclicality of employment in firms at the manufacturing sector in Brazil 
over the period 2000-2014. The main conclusion of the study is that the relationship between productivity, wages and employment size are not strong as it was suggested by other studies. Furthermore, their findings show that high-productivity firms are proportionally destroying more jobs during recessions and create more in booming and expansion periods. Furthermore, researchers have addressed that access to finance and credit is an important factor for the employment growth, which is also strongly related to our study, since it is one of the main component of the SBRs explored. In particular, Fort et al. (2013) argue that younger firms have less exposure to financial and credit markets and rely heavily on personal financial sources. Studies exploring the relationship between firm size, age and credit in the USA following the great recession of 2007-2008, suggest that under extreme credit lunch conditions, financial constraints are more binding to small, younger and low wage firms (Moscarini and Postel-Vinay 2016; Haltiwanger et al. 2018).

A number of studies have explored the determinants of job creation rates in the MENA region countries. Arouri et al. (2016), investigated the impact of regulation and fiscal policies on job creation outcomes for small and young firms in Tunisia during the period 1996-2010. The authors found that small and newborn firms create more jobs; however, the Tunisian economy is struggling from fundamental issues, such as structural unemployment and the inability to absorb the unemployed youth. Furthermore, the majority of the firms is active on the traditional sectors and not technological start-ups with high productivity, leading to increase of employment for unskilled workers. Thus, educated people are less likely to find a job, resulting to a decrease of productivity in the long-run and weakening the dynamics of the job creation. These findings confirm also the concluding remarks derived in the studies by Bartelsman et al. (2019) and Hawash and Lang (2020) discussed earlier, highlighting that ICT, which can be part of the technological start-up business, can have a considerable positive impact on productivity and economic growth. McArthur and Teal (2002) conducted a micro-data level analysis to explore the impact of corruption on firm performance in 27 African economies using data from the Africa Competitiveness Report in 2000-2001. Their results show that firms paying for bribes are more likely to report a lower level of output per worker by 20 percent compared to firms that do not pay.

Industrial policies, government expenditures and investment on infrastructure are important factors of SBRs and economic growth. For instance, Ferraz et al. (2015) examined the role of government procurement contracts on the economic growth in Brazil. More specifically, the authors explored whether firms that bid and win those contracts are more likely to grow further compared to firms that do not win. A unique dataset that links employees and employers over the period 2004-2010 is used and it is found that at least one contract raises the firm's growth in a given quarter by 2.2 percentage point. Furthermore, the 93 percent of the new jobs is coming from either the informal sector or from unemployment. Furthermore, Ferraz et al. (2015) address in their study the issues related to credit constraints young and small firms are facing and how policies removing those barriers may allow firms to grow.

Similarly, the studies by Dollar et al. (2003), Subramanian et al. (2005), Fajnzylber et al. (2009) and Hansen et al. (2009) show that effective SRBs and an efficient business and investment climate are major factors of economic growth. For 
example, Dollar et al. (2003) using data from the World Bank for firms in Bangladesh, China, India and Pakistan explored the relationship between firm performance and investment climate. In particular, they proxied the investment climate by the time spent with government bureaucracy, days required to set up a phone line and to clear customs for imports-exports, and sales which are lost due to power outages. Their main concluding remark is that returns on wages and profit are significantly higher when the investment climate and infrastructure perform well. Fajnzylber et al. (2009) employed data for Mexican firms and explored the effect of the government support on the probability of business survival, where government support includes training programs, tax credits and access to finance and credits. Even though their results suggest an overall insignificant impact on firm profitability, access to credit is an important determinant of the firm performance. In a similar fashion, Hansen et al. (2009) show that an effective business and investment climate, which is expressed by support for start-up firms in Vietnam, increase the economic growth, while Subramanian et al. (2005) found that an ineffective investment climate and poor interactions between the state and businesses have adverse effects on total factor productivity of firms in Brazil and China. Goedhuys et al. (2016) examined also the impact of corruption on firm growth and innovation using a sample of 2897 firms in Egypt and 592 in Tunisia derived from the World Bank Enterprise Surveys over the period 2013-2014. The authors confirm the negative effect of corruption on the firm growth, the trust in the government leading to disinvestments and leaks in the national welfare.

The most related study to ours, is the report by Amin et al. (2016) who found that political instability, corruption, inadequate electricity supply and constraints to access to finance are negatively related to firm performance. More specifically, the authors explored the role of SBRs on labor productivity, sales and employment growth in eight MENA countries during the period 2008-2013, and they identified political instability, electricity supply and corruption as the three main obstacles in SBRs. However, their analysis is limited to graphical representations and correlation analysis showing that the majority of the respondents stated the above mentioned obstacles as the main drivers of low firm performance. Therefore, our analysis moves one step further, as it aims to establish a quantitative relationship between SBRs and job creation. Political instability and electricity supply are two main obstacles in the SBRs and economic growth. For example, the conflict in the republic of Yemen in 2011-2012 has had a strong impact on power supply, where entire cities have been without electricity for months, compounded by bombing campaigns that have destroyed existing power grids. According to Stone et al. (2012), the $90 \%$ of the firms in 2012 reported that their businesses lost their power due to the conflict, a number which definitely was not improved in the midst of the upheaval. On the other hand, the energy demand in Egypt has past the capacity in 2013, and it was growing by $6 \%$ per annum, due to a growing population and energy-intensive investments followed by massive and repeated power outages (World Bank 2013).

Furthermore, Sabry (2019) explored the role of the SBRs in the MENA region and the post-Arab Spring period. The author divided the countries into four categories based on their development following the Arab Spring, and more specifically, in Gulf; militarizing; liberalizing and civil war states. The analysis is based on an OLS 
multivariate panel regression over the period 1995-2017 and the sample includes firms from 18 MENA countries. However, the SBRs explored are quite different, as the author used four modes of SBRs and in particular, predation, which refers to the situation where state officials misuse their power and control over resources in order to gain benefits and increase their wealth (Evans 2012), and state capture, where influential and powerful businessmen shape regulations and laws matching their interests (Adly 2009). The third measure of SBRs is the cronyism, which refers to preferential treatments between officials and politically connected business persons that target to achieve extraordinary returns (Mazumdar 2008). The last measure is collaborative governance, which is a type of a collective public-private governance, aiming to create rules and laws regulating the provision of public goods (Ansell and Gash 2007). Nevertheless, the main outcomes of interest differ from our study, as the main outcomes explored include the GDP growth, industrial labor productivity, innovation and the private investment share. Overall, the findings support that effective and formal SBRs can encourage growth. However, we can argue that those outcomes can drive employment growth, thus, the paper by Sabry (2019) is related to the objectives of the current study.

\section{Methodology and data}

\subsection{Job flows}

In this section, we describe the main outcomes of interest and in particular the job flows employed in the study (Davis and Haltiwanger 1990, 1992; Aga et al. 2015). While the main outcome of interest is the net job creation rate, we also aim to explore the role of SBRs and other factors on the gross job creation and destruction rates, since these factors may not have the similar impact on gross and net job creation rates (Hallak and Harasztosi 2019). In order to find the net job creation rates, we need to follow the next steps. First, we define the following variables: the number of Units $(I)$ which is the number of active units in a cell $c$, such as young and small-medium firms. The second variable used is the employment $(E)$, which is defined as the sum of employment across all firms in a cell $c$ as:

$$
E_{c t}=\sum_{i=1}^{I} E_{i t}
$$

where $i$ refers to firm and $t$ to time-year. The first two measures we explore is the job creation and destruction rates. In particular, gross job creation is the sum of the expanding and new establishments within a sector, while the gross job destruction is derived by the sum of employment losses at shrinking establishments within a sector. The job creation rate (JCR) over the average employment in the 2-year period is:

$$
J C R_{c t}=\frac{\sum_{i=1}^{I}\left(E_{i, t}-E_{i, t-1}\right)}{0.5 \cdot\left(E_{c, t}+E_{c t-1}\right)}, \quad \text { for }\left(E_{i, t}>E_{i, t-1}\right)
$$

Similarly, the gross job destruction rate $(J D R)$ is defined as: 


$$
J D R_{c t}=\frac{\left|\sum_{i=1}^{I}\left(E_{i, t}-E_{i, t-1}\right)\right|}{0.5 \cdot\left(E_{c, t}+E_{c t-1}\right)}, \quad \text { for }\left(E_{i, t}<E_{i, t-1}\right)
$$

Next we take the difference of (2-3) to calculate the net job creation rate (NJCR) and it will be:

$$
N J C R_{c t}=J C R_{c t}-J D R_{c t}
$$

\subsection{Main empirical framework}

The general regression for the job flows takes the following form:

$$
Y_{k, j, t}=\beta_{0}+\beta_{1} S B R_{k, j, t}+\beta^{\prime} X_{k, j, t}+\mu_{k}+l_{j}+\theta_{t}+\varepsilon_{k, j, t}
$$

$Y$ denotes the outcome of interest, which includes the job creation and destruction rates and the net employment growth for industry $k$, in district-governorate $j$ and time $t$. SBR denotes the obstacle each of the state-business relation explored and $\mathbf{X}$ is a vector of standard control variables, which are discussed below. Set $\mu_{k}$ controls for fixed-industry effects, set $l_{j}$ denotes the district-governorate fixed effects, and $\theta_{t}$ is the time-fixed effects, while $\varepsilon$ is the error term. Following earlier studies, in vector $\mathbf{X}$ we include various firm characteristics to explore their relationship to the main outcomes and these are reported in Table 1 . SBR is a dummy variable taking value 100 if the respondent reports that there is a major or very severe obstacle and 0 if it is moderate, minor or there is no obstacle, therefore the estimated coefficients should be interpreted as percentages.

Next we discuss the control variables included in the regression analysis, which are chosen based on the data availability and earlier studies. The first two variables refer to firm size and age expressed respectively as the logarithm of the total number of full-time permanent employment and the number of years the establishment has been in operation. Regarding the firm size an issue is that we are unable to capture precisely the firm size given the fact that it can be a part of another firm. Nevertheless, we control for this, as we discuss later. Moreover, we include a quadratic term in firm size and age following the studies by Jovanovic (1982), Evans (1987a, b) and Lawless (2014). The quadratic term in firm size will allow us to explore Gibrat's law where the size and growth are independent. Therefore, based on the earlier literature the relationship between job flows and firm size can be mixed. However, we aim to explore whether there is a quadratic relationship, implying that the firm size can be positively correlated with job creation, but the rate of job creation declines. Regarding firm age, Lawless (2014) explored different age groups where an inverse relationship between employment growth and lagged size for the young firms was found, but this declines in magnitude when they implemented the analysis separately for older age groups. For this reason, we include also the quadratic terms in firm size and age to explore whether the size or age matter and whether a firm has reached a mature state. 


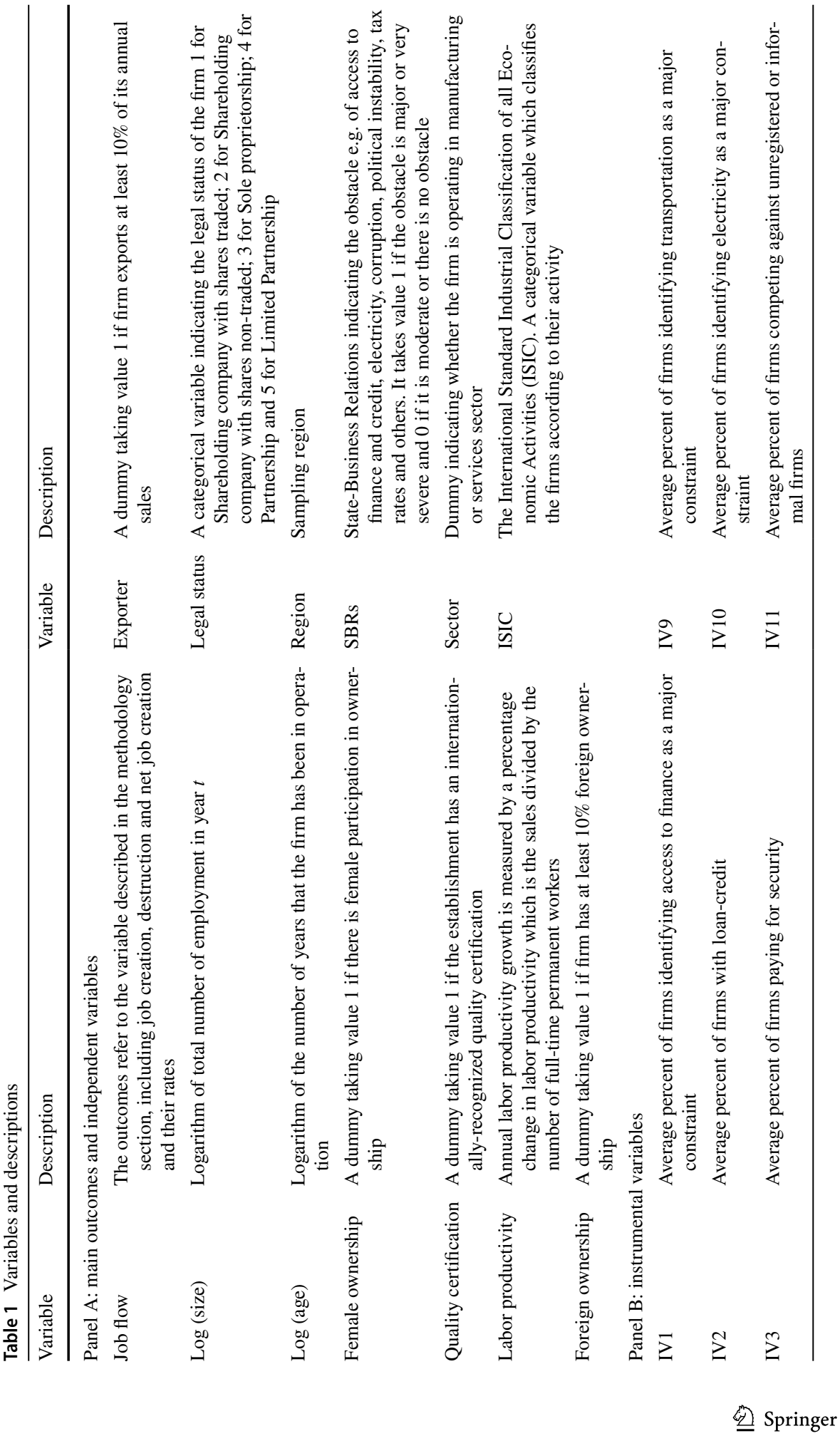




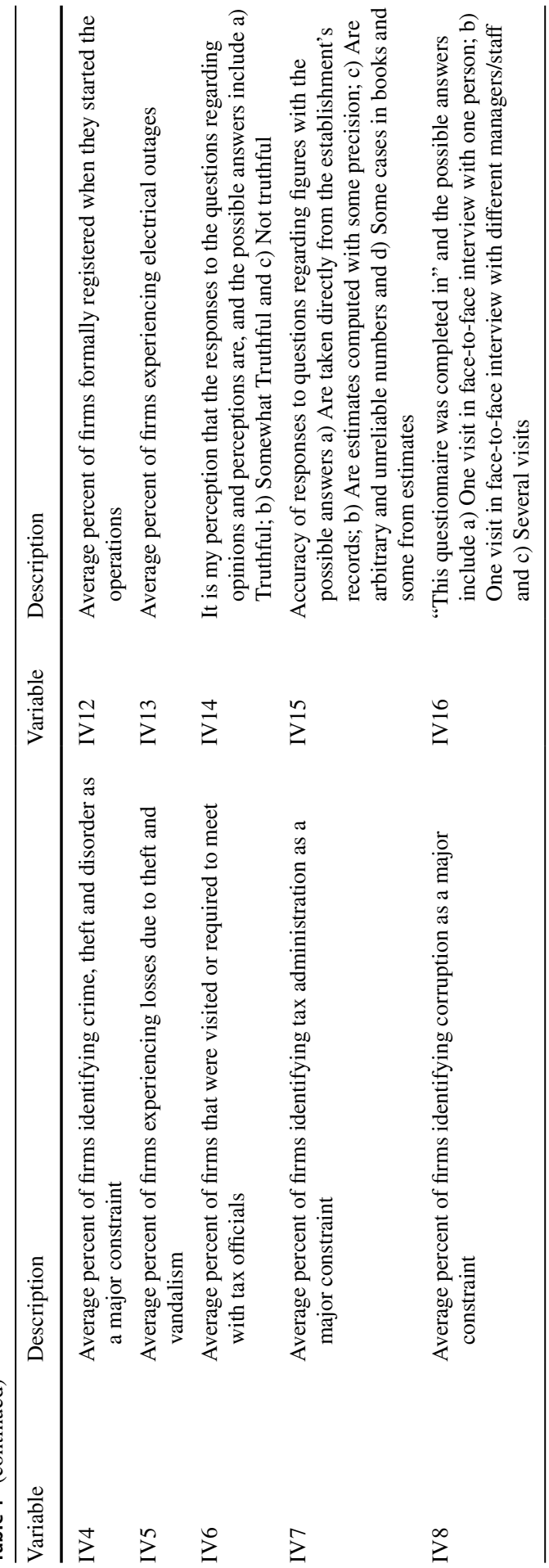


Another interesting variable is the gender of the ownership. Previous studies found that women are more risk averse and more likely to invest in activities with lower risk than men (Croson and Gneezy 2009; Faccio et al. 2016). As before, this literature refers to the firm growth and exiting rates, but since we analyze the employment growth and job creation, this variable can be strongly related to our topic. Thus, our assumption is that female ownership will be positively correlated with the job creation. The variable is reported in Table 1 and it takes value 1 if there is at least one female owner and 0 otherwise. However, one main drawback of this determinant is that we have not got information on the number of female owners, but the question records only the case whether at least one of the firm owners is female or not.

Based on the data availability and information recorded on the World Bank ES, Labor productivity is measured as the sales divided by the full-time employees. The hypothesis lies in the fact that labor productivity has a positive impact on firm financial performance, economic growth, attracting more people and creating more jobs (Kazuya 2009; Wu 2013).

The next two factors explored are whether the firm is an exporter and whether the establishment is granted with an international certification of quality. In terms of the link between job creation and export expansion, earlier studies found that increase in exports can lead to higher levels of derived labor demand, especially for the transition and developing economies, such as Egypt and Turkey. One explanation justifying this relationship lies in the fact that exports in those countries are labor intensive, including agriculture and foods, furniture, apparel, footwear and textiles (Vu et al. 2013, 2016; Kien 2015). In other words, these economies rely on an export promotion that exploits the comparative advantages of producing labor-intensive goods. On the other hand, this may not necessarily hold for the industrial and developed economies that are more technologically and capital intensive; however, this is out of the current study's topic. Hence, expansion of exports may become an important determinant of employment growth. In line with this, we explore also whether the manufacturing sector creates more jobs than firms in the services sector. According to Table 1, this variable obtains value 1 if the firm exports at least the $10 \%$ off its annual sales. While on the one hand, we may support the argument that manufacturing sector creates more jobs due to export expansion, on the other hand, services may contribute more to job growth, given the fact that developing economies have expanded also the services sector over the last decades.

Regarding the accreditation of an international quality certificate, such as the International Organization for Standardization (ISO) 9001, the variable takes value 1 if the firm has been accredited with such a certificate and 0 otherwise. The main hypothesis is a positive role of quality certification on firm performance, costs savings, improvement of customers' satisfaction, increase in productivity and job growth. In particular, the literature suggests that firms adopting quality management schemes may address risks, preventing potential production failures and improving their performance, bringing benefits to the firms that implies expansion of their operations increasing the labor demand (Corbett et al. 2002; Naveh and Marcus 2005; Lafuente et al. 2010; Ullah et al. 2014). 
Firm's ownership is another variable and is defined by a dummy taking value 1 if the establishment has at least 10 percent foreign ownership. The nature of the firm's foreign-ownership has been explored in earlier studies (Bernard and Sjöholm 2003; Baldwin and Yan 2011; Gelübcke and Wagner 2012). These studies used this variable based on the assumption that foreign-owned firms could face lower probabilities and risk of exit due to international links, economies of scales, access to information and markets and possible favors in terms of tax treatment. Moreover, these firms are more likely to export the goods, and based on the previous assumption, foreign ownership is more likely to be positively associated with job creation. On the other hand, also foreign-owned firms may face problems related to lack of knowledge of the local market and culture.

Other control variables include the region showing the regional units, such as North Upper Egypt, or Southern Upper Egypt for Egypt and Marmara, Aegean, Mediterranean, Central Anatolia and Black Sea region for Turkey and so forth; and the legal status of the firm, which is a categorical variable indicating the structure of the firm, such as whether its shares are traded or non-traded in the stock market or whether is partnership or limited partnership.

\subsection{Data}

The analysis relies on data derived from the Enterprise Surveys (ES) provided by the World Bank. ${ }^{1}$ The surveys are stratified by firm size, industry and geographical location, which shows that the sample could be quite representative. The sample is 3557 firms in Egypt and 2496 firms in Turkey and the main period of analysis is the years of 2008 and 2013. We should notice that these surveys include also the panel component where the same firms are followed in two years. Nevertheless, we follow the strategy of earlier studies and we make use of the full cross section surveys, including both panel and non-panel component, which provides us the possibility to view and follow a comparative analysis of the trends across the two economies (Aga et al. 2015).

The World Bank (ES) cover many topics followed by a core questionnaire that allows us to make a comparative analysis across firms, sectors, countries and years. The core questionnaire contains questions answered by the business owners and high ranked managers providing objective, but also subjective information about the business environment. More specifically, the subjective questions refer to evaluations about the severity of obstacles that firms face. The interviewers ask firms to rank 15 components of the business environment, indicating which one presents the largest obstacle and to rank them on a scale of $1-5$, with 1 being no obstacle and 5 being a severe obstacle.

In Figs. 1 and 2, we illustrate the major obstacles in SBRs respectively in Egypt and Turkey. The reason of presenting those figures is that we aim to examine the impact of the most significant SBR separately to be able to disentangle their effects.

1 Enterprise Surveys (https://www.enterprisesurveys.org), The World Bank. 


\section{Major Obstacles}

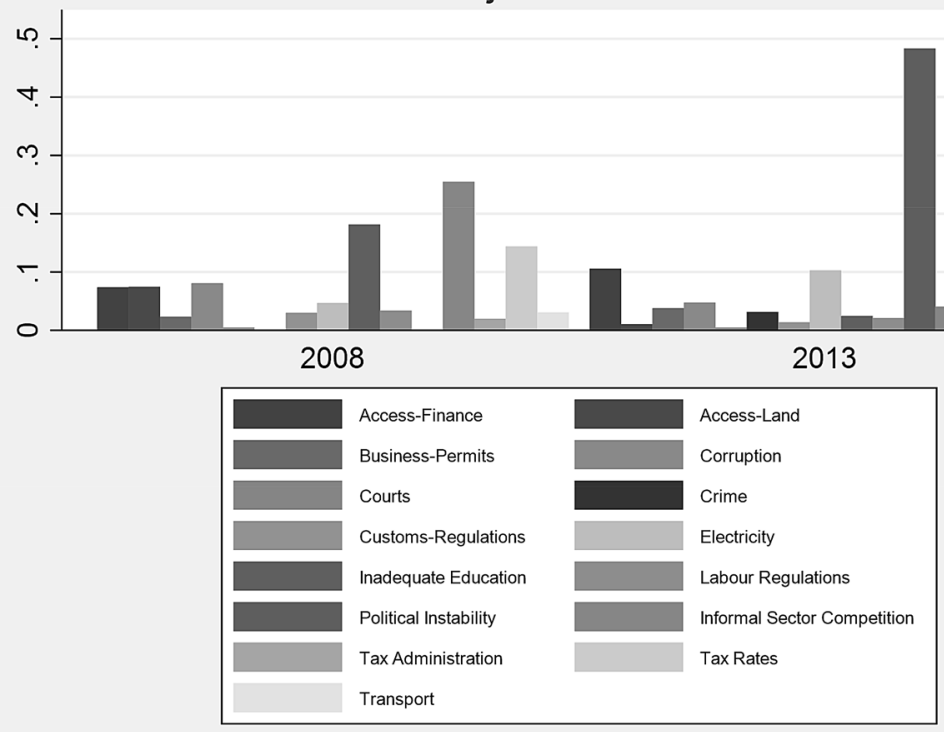

Fig. 1 Major obstacles in SBRs for Egypt

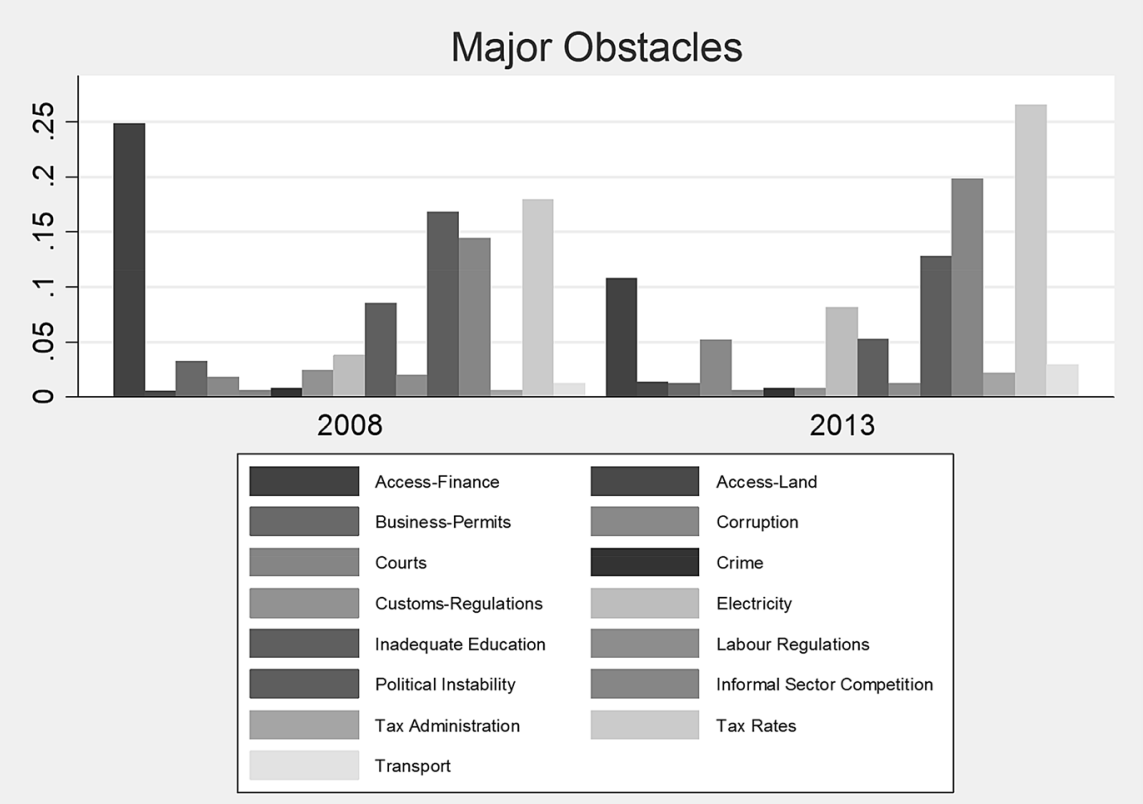

Fig. 2 Major obstacles in SBRs for Turkey 
The figures are based on proportions about how the respondents evaluate the obstacles and which ones affect mostly the operation of the establishment. While we could include them in one regression, this could create problems with multicollinearity which will not allow us to explore the actual impact and unable to disentangle their effects. On the other hand, we could create an index using all the 15 obstacles within a factor or principal component analysis. However, we are not interested on the effect of the SBRs in total, but we aim to explore individually the impact of the major obstacles in SBRs, so creating an aggregated index will not be useful to our analysis.

In Fig. 1, we observe that the major obstacles affecting the operations of the establishment include the access to finance and credit, electricity, corruption and political instability. Even though the corruption is dropped in 2013, it still remains one of the most important obstacles in SBRs in Egypt. Furthermore, we show that inadequate education has presented a dramatic reduction in 2013 and hence, we will exclude it from the analysis. On the other hand, there is a very large increase in the proportion of firms reporting that political instability is the most important obstacle to business activities, reflecting the Arab spring and the Egyptian Revolution of 2011 along with the relevant protests and uprisings followed during this period. Thus, we will limit our analysis to the four most important obstacles mentioned above. Based on Fig. 1, the $9 \%$ of the firms in 2008 report access to credit and finance as a very severe or major obstacle, increasing at $11 \%$ in 2013 . Political instability illustrates the higher proportion as the major obstacle in SBRs and the highest increase from $19 \%$ in 2008 to $49 \%$ in 2013. Corruption reduced by 2 percentage points between 2008 and 2013, and in particular, from 9 to $7 \%$, while the proportion of the respondents reporting electricity supply is a major or very severe obstacle increased from 5 percent in 2008 to almost 10 percent in 2013 . We should notice that SBRs are illustrated by row. For instance, the first bar in Fig. 1 and year 2008 refers to access to finance, the second bar refers to access to land, the third bar refers to courts and so forth.

Similarly, in Fig. 2 we observe that the major obstacles in SBRs in Turkey is the access to finance and credit; inadequate education; political instability; practices of competitors in the informal sector and tax rates. Nevertheless, we observe a large reduction in 2013 for the obstacle related to access to finance, inadequate education and political instability, but a large increase in tax rates and competition from firms operating in the informal sector. Also, we note an increase in corruption and electricity. Even though the reduction in access to finance and political instability has been noted, we will explore them as they remain two of the four most important obstacles in 2013. Additionally, we will explore the tax rates and competition from the informal sector. In particular, according to Fig. 2, the 25 percent of the respondents reported that there are major or severe obstacles to access to finance and credit in 2008 and reduced at 11 percent in 2013. Political instability reduced from 17 percent in 2008 to 13 percent in 2013. On the other hand, informal sector competition increased from 14 percent in 2008 to 19 percent in 2013, while tax rates presented an increase of 9 percentage points between 2008 and 2013, from 18 to 27 percent.

Following Aga et al. (2015) in order to yield accurate population estimates for the main parameters of interest in the empirical work of this study, we account 
Table 2 Job flow rates by sector

\begin{tabular}{llll}
\hline Sector & $\begin{array}{l}\text { Gross job crea- } \\
\text { tion rate }(\%)\end{array}$ & $\begin{array}{l}\text { Gross job } \\
\text { destruction rate } \\
(\%)\end{array}$ & $\begin{array}{l}\text { Net job } \\
\text { creation rate } \\
(\%)\end{array}$ \\
\hline Panel A: Egypt & & & \\
All & 3.896 & 4.008 & -0.034 \\
Manufacturing & 5.221 & 5.202 & 0.019 \\
Services & 0.584 & 0.677 & -0.092 \\
Panel B: Turkey & & & \\
All & 2.443 & 2.528 & -0.085 \\
Manufacturing & 2.840 & 2.741 & 0.099 \\
Services & 0.984 & 1.137 & -0.152 \\
\hline
\end{tabular}

Table 3 Job flow rates by firm size

\begin{tabular}{lcll}
\hline Firm size & $\begin{array}{l}\text { Gross job crea- } \\
\text { tion rate (\%) }\end{array}$ & $\begin{array}{l}\text { Gross job destruc- } \\
\text { tion rate }(\%)\end{array}$ & $\begin{array}{l}\text { Net job } \\
\text { creation rate } \\
(\%)\end{array}$ \\
\hline Panel A: Egypt & & \\
$5-19$ & 7.534 & 8.756 & -1.222 \\
$20-99$ & 8.582 & 9.564 & -0.982 \\
+100 & 9.459 & 8.127 & 1.332 \\
Panel B: & Turkey & & \\
$5-19$ & 2.369 & 2.373 & -0.004 \\
$20-99$ & 2.739 & 2.710 & 0.029 \\
+100 & 2.915 & 2.895 & 0.020 \\
\hline
\end{tabular}

for sampling weight in both descriptive statistics presented in this section, and in the regression analysis illustrated in the empirical results section. In Table 2 we report the job flow rates by firms in the services and manufacturing sector, while in Table 3 we present the flow rate by firm size. We observe similarities between the two economies, as the net job flows are positive in the manufacturing sector, and they become negative in the services sector and the total economy. In Table 3 we observe that large firms in Egypt create more jobs and more specifically firms with more than 100 employees, while small-medium enterprises destroy more jobs than they create. On the other hand, in Turkey we show that only the small firms with less than 20 employees create less jobs, while firms with more than 19 employees present a positive net job creation rate, even though this is relatively low.

In Table 4 we report the summary statistics using sampling weights for the main control variables. The purpose of presenting the descriptive statistics is not only to highlight the similarities, but most importantly to identify the differences that characterize the firms across the two economies explored. Regarding firm size and age we observe that the averages are very close to both economies, where the average number of employees is 88 and the average age is 21 in Egypt, 


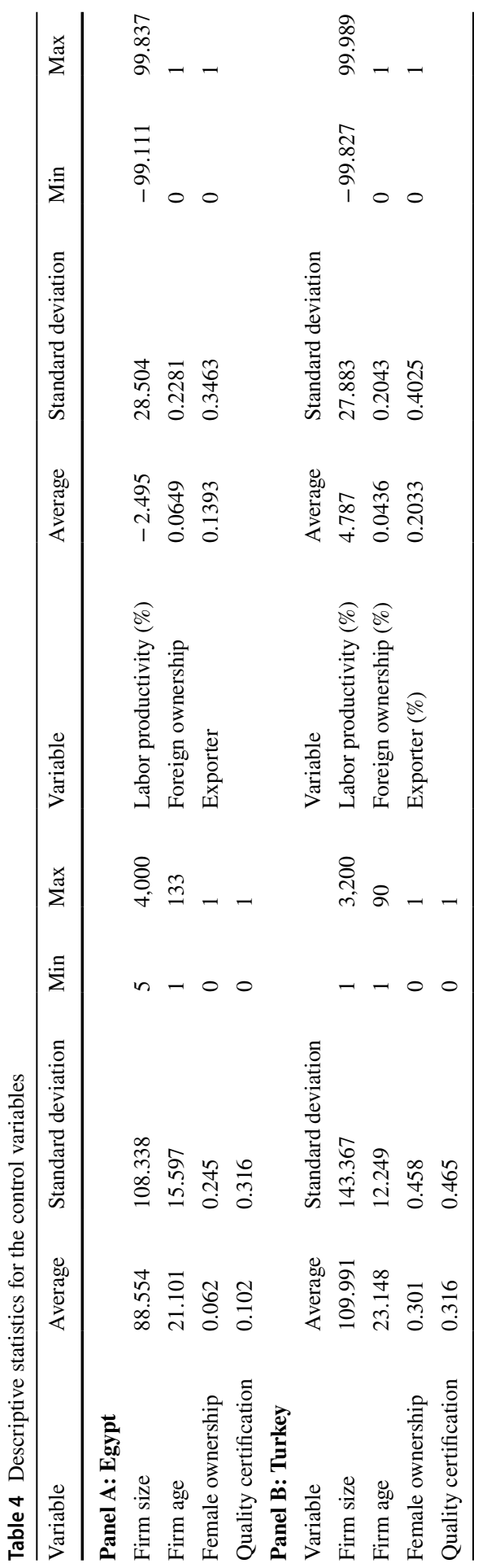


while the respective values in Turkey are 110 employees and 23 years. However, the rest of the variables present large differences between the two countries. For instance, the female ownership in Egypt is only 6.2 percent, while the percentage in Turkey reaches the 30 percent. This shows that female entrepreneurship is more common in Turkey, while women in Egypt have rather less opportunities to establish or take part to business activities. Regarding the international quality certification only the 10.2 percent of the sample has been accredited with it in Egypt compared with the 31.5 percent in Turkey. Also, differences are observed in the firms defined as exporters which is 14 percent in Egypt compared to 20 percent in Turkey. These statistics illustrate the openness of the firms, which is significantly higher in Turkey. Moreover, the average labor productivity in Egypt is negative at -3 percent, while in Turkey is positive and equal at 4.8 percent.

\subsection{Endogeneity and instrumental variables (IV) approach}

We should notice that our main variable of interest, which is the SBRs, may be endogenous to firm growth implying the coefficients derived by the effect of regression (5) would be invalid. The three main courses of endogeneity include the omitted variables bias, self-statement and perception about the obstacles and reverse causality. Regarding the first source of the endogeneity issue, and the omitted variable bias, it is unclear if effective SBRs are random. For instance, firms operating in specific sectors, industries and locations may face higher obstacles, such as bribing, corruption and utilities supply, including electricity, water, energy and transportation. Moreover, two firms operating in the same sector or industry, they may need to pay different amounts in bribes and face different degrees of corruption, but also the impact of obstacles in access to finance and credit, tax rates, electricity supply and competition from the informal sector on their growth may vary. Hence, SBRs can be endogenous, because firms may choose to locate in cities and areas with better investment climate and lower obstacles in SBRs. These differences may be correlated with unobservable characteristics influencing the growth trajectory and job creation of the firms.

Regarding the second source of the endogeneity issue, some managers may report obstacles that are actually overestimated or underestimated, or there could be cases where some inefficient firms may overstate the constraints and obstacles that they actually face (Beck et al. 2005a; Carlin et al. 2006). Therefore, SBRs may be endogenous either because of measurement error due to perception, but also because of possible reverse causality between SBRs and the outcomes of interest explored in the study. In particular, while SBRs may affect job flows, we can argue that also employment growth may have an impact on the quality of SBRs.

Even though we may reduce the endogeneity issue by employing the panel dataset, aiming to remove time-invariant location-region, and industry characteristics, we also implement the Two-Stage Least Squares (2SLS) method and we use two sets of instrumental variables for SBRs which are available in the ES. More specifically, we employ 16 instruments reported in Table 1, where we classify the first 13 
variables into the first set, and the second set includes 3 variables, which refer to the interviewer's evaluation.

For the first set of instruments used we follow similar procedures from earlier studies (Dollar et al. 2005, 2006; Escribano and Guasch 2005; Commander and Svejnar 2007; Fisman and Svensson 2007; Dethier et al. 2010; Şeker 2011; Aterido et al. 2011; Şeker and Yang 2014), which is the average percentage of the variables reported in Table 1 by industry-sector-location. The justification of the underlying validity of the instruments at industry-sector-location averages lies on the fact that the firms apart from their characteristics are also dependent on government services, public infrastructure, location, sector and industry factors, which are presented in panel A of Table 1. This setting allows for a correlation between SBRs and the industry-sector-location averages, but they should be however, uncorrelated with unobservables that may be correlated with job flows (Collins et al. 2009).

Hence, in order to address the endogeneity issue coming from the reverse causality between the outcomes and the factors of main interest-SBRS-we assume that obstacles in SBRs are determined by the underlying characteristics of the specific location and industry-sector of the firm. It is assumed that the average percentages of the variables for a sample of firms belonging to the industry-sector-location group, is representative for the firms in that group and for each firm the cluster average excludes the individual obstacles in SBRs. Hence, while local conditions of the SBRs at the industry-sector-location can explain the variation on the job flows of the firms, the employment growth of an individual firm will have no impact on the industry-sector-location average of the variables IV1-IV13 in panel B of Table 1.

The second set includes the variables IV14-IV16 in panel B of Table 1. In particular, the first variable is completed by the interviewer and the question is "It is my perception that the responses to the questions regarding opinions and perceptions are", and the possible answers include (a) Truthful; (b) Somewhat Truthful and (c) Not truthful. The second variable answers to the question "Accuracy of responses to questions regarding figures" with the possible answers (a) Are taken directly from the establishment's records; (b) Are estimates computed with some precision; (c) Are arbitrary and unreliable numbers and (d) Some cases in books and some from estimates. The third variable answers to the question "This questionnaire was completed in" and the possible answers include (a) One visit in face-to-face interview with one person; (b) One visit in face-to-face interview with different managers/staff and (c) Several visits.

Our suggestion of using these three categorical variables lies in the argument that they are correlated with the state-business perceptions and cannot directly affect the outcomes of interest. About the first two variables, even though the state-business relations can have an impact on firm's performance, the judgment and perception of the interviewer cannot affect them, but it may have a correlation with the reliability of the individual's response. In a similar study, Cojocaru (2012) uses the interviewer's assessment and perception as an instrumental variable to rank each household's well-being and the results remain robust. Therefore, we argue that these instruments can be correlated with the obstacles in the SBRs, but cannot influence the outcomes of main interest-job flows. The third variable can be also a candidate instrument, as the perception about obstacles and state-business relation may vary depending on 
whether the questions are replied by the same or a different person, but even by the same person across several visits. This will also be confirmed by our 2SLS estimates where the endogeneity hypothesis is rejected; implying that conditioning on these variables there is no correlation between the instruments, outcomes and the error term. Furthermore, in all cases we reject the null hypothesis that instruments are weak.

\section{Empirical results}

\subsection{Main results}

According to Tables 5, 6, the first major and common obstacle in the SBRs across Egypt and Turkey is the access to finance and the second is the political instability. The remained two obstacles differ, as in Egypt is the electricity and corruption, while for Turkey is the tax rates and practices of competitors in the informal sector. Obstacles regarding the firms' access to finance and also corruption allow large firms to be unfairly subsidized and small firms more "taxed" creating less jobs in the economy. Large firms in both countries have not actually grown in the process and therefore have not created more jobs, but are born large and are results of the privatization process of public and state-owned firms, including supply of power, post offices, telecommunications and transportation (Şeker and Correa 2010; World Bank 2014). These obstacles are more common to small-medium firms making them unable to compete with the old and large privileged firms. Constraints to access to finance and political instability have a negative impact on the net job creation rates in both countries, while the 2SLS coefficients are higher indicating that OLS may underestimate the real effect of these obstacles. Furthermore, we find a positive and significant coefficient in the gross job destruction rate in Egypt, indicating that firms facing severe and major obstacles in access to finance are more likely to destroy more jobs compared to those reported moderate or no obstacles. On the other hand, the coefficient is insignificant for Turkey.

Previous studies confirm that constraints about access to finance are reported more frequently to small-medium firms and have less access to formal sources of external finance (Beck et al. 2005b; Beck and Demirguc-Kunt 2006). This can be explained by poorly developed capital markets, but also by the corruption that favors mainly the large and privileged firms and isolate the small firms that are in more need of financing their operations. These limitations have a negative impact on firm's performance, including financial performance and sales and thus, an overall negative effect on employment growth (Klapper et al. 2006).

In line with limitations and constraints on access to finance we observe also that the competition from firms in the informal sector is another major obstacle of SBRs in Turkey. This can be also a result of the related constraints to finance and credit that forbid the firms in the formal sector to employ more workers. This is also connected with the tax rates, which is a major constraint in Turkey. More specifically, high tax corporate taxes will create obstacles to firms, and especially the small firms that are in more need for finance and capital, allowing workplaces 


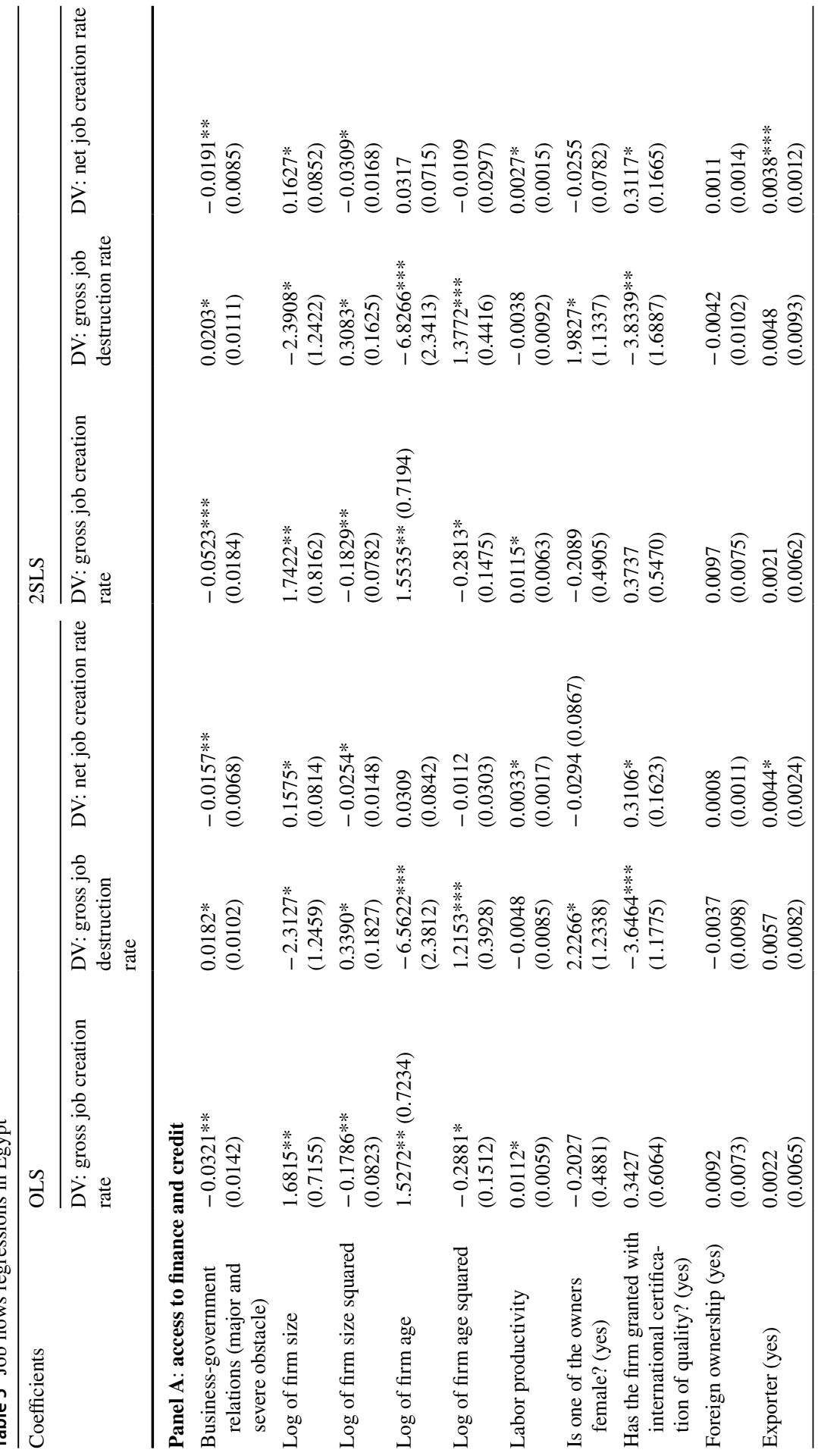

\section{글 Springer}




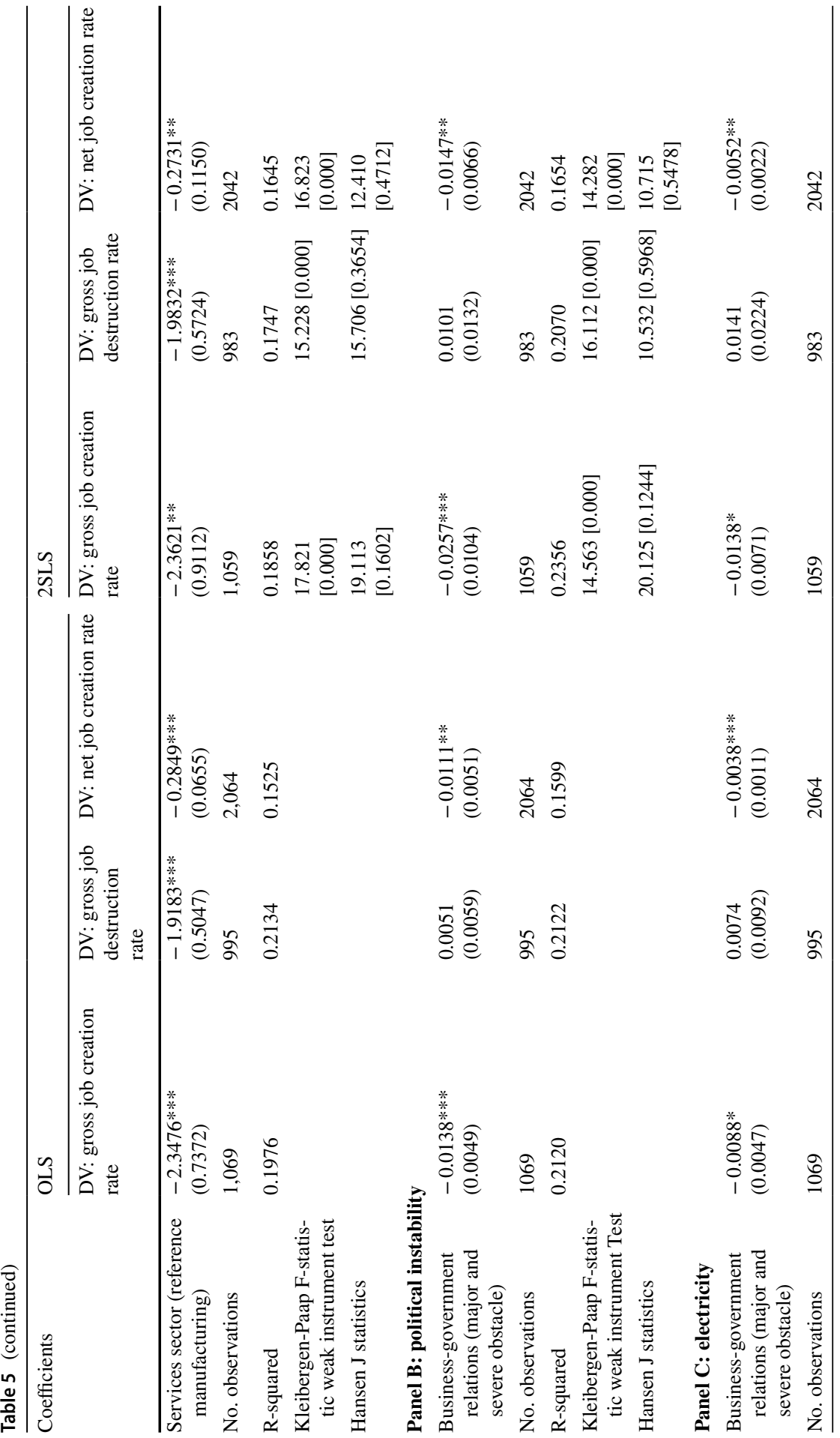




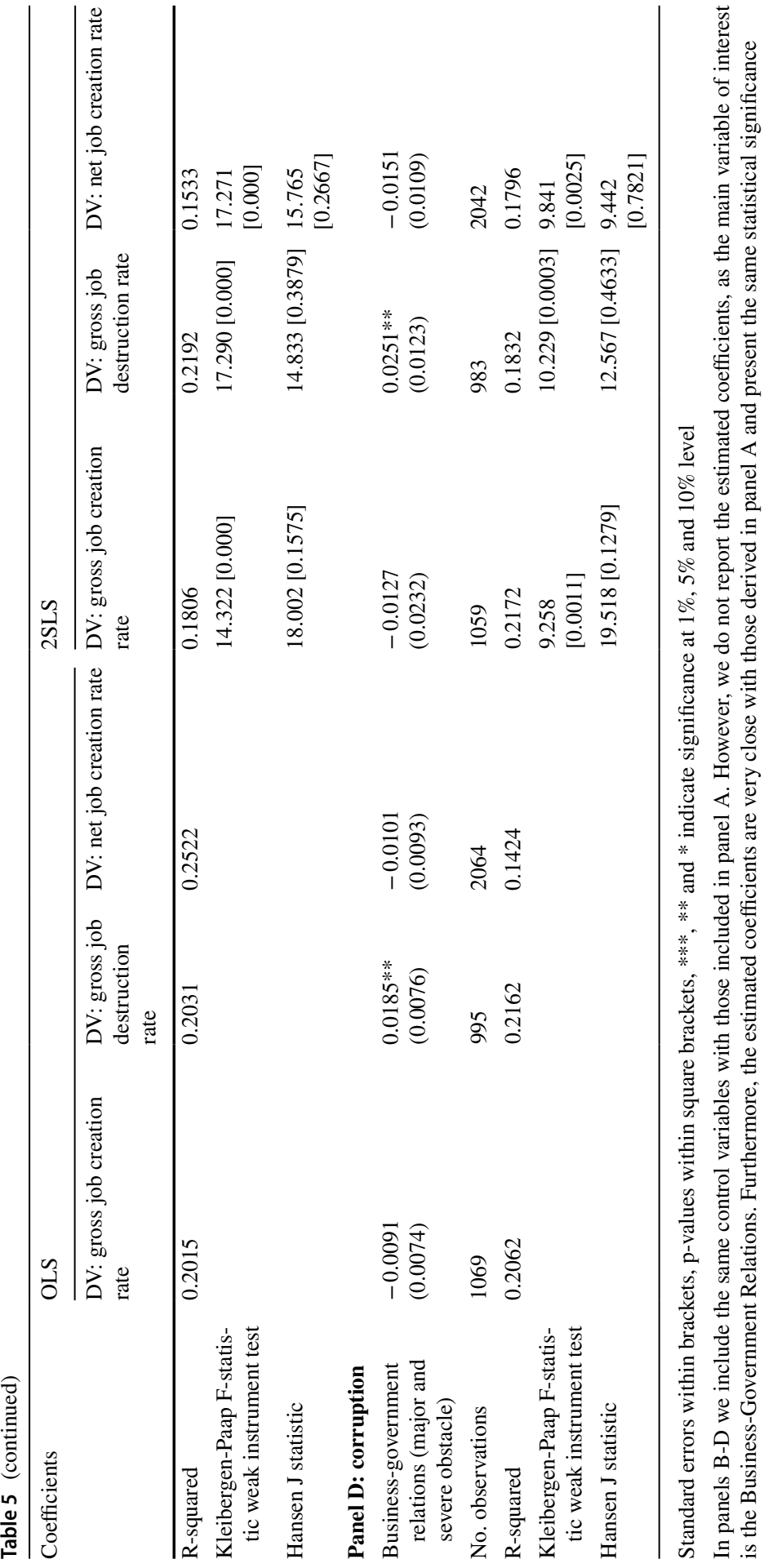




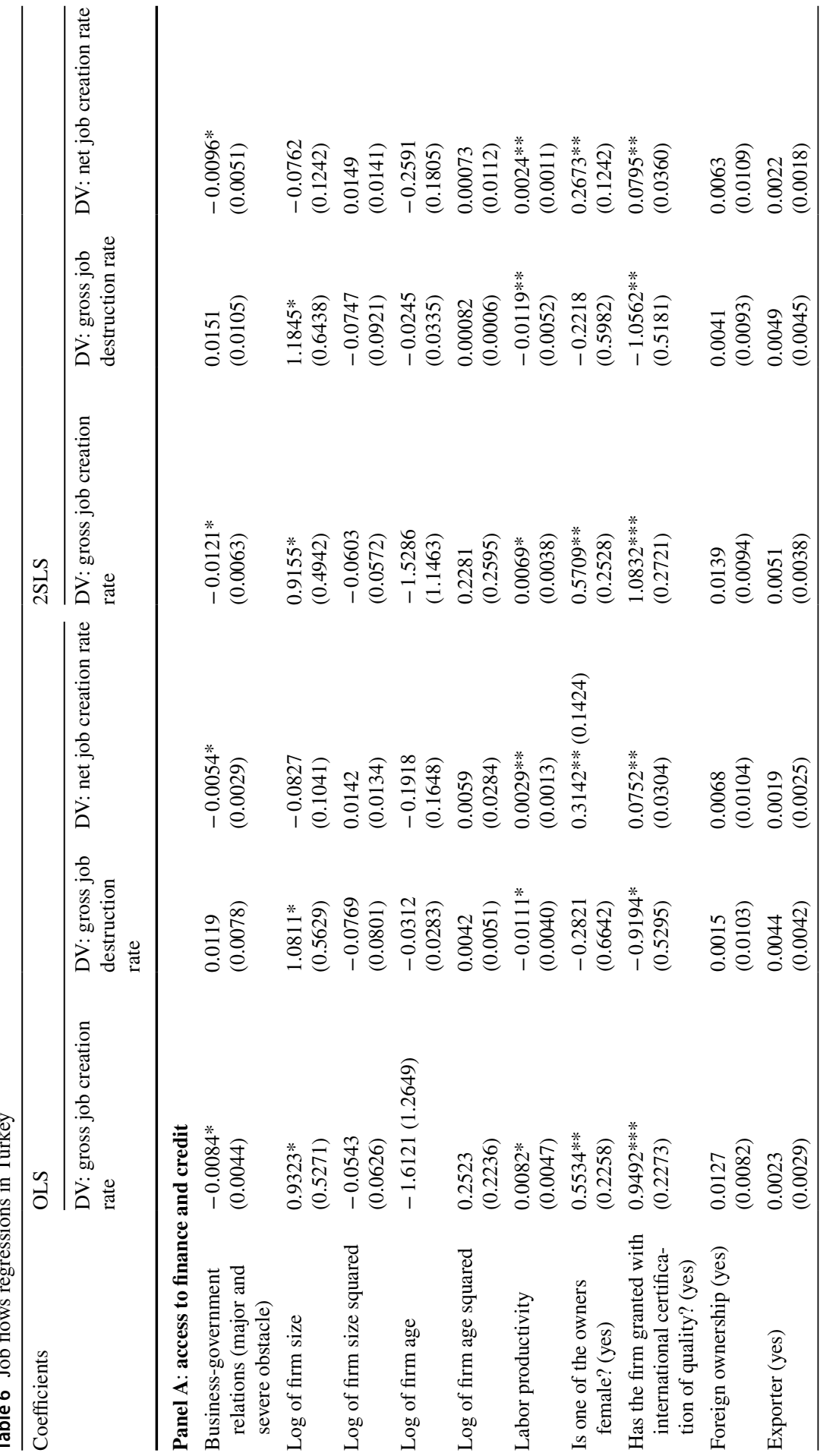




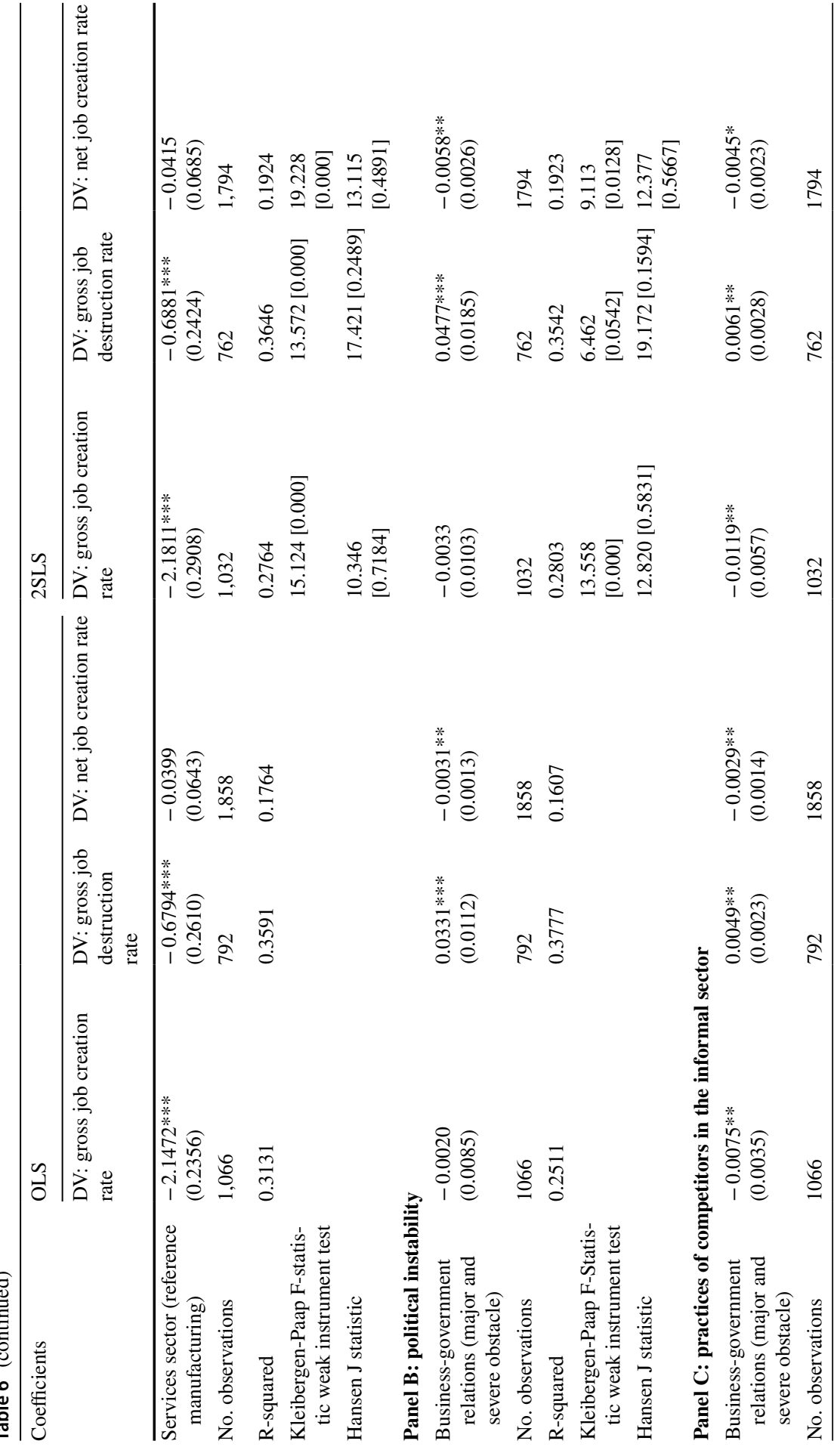




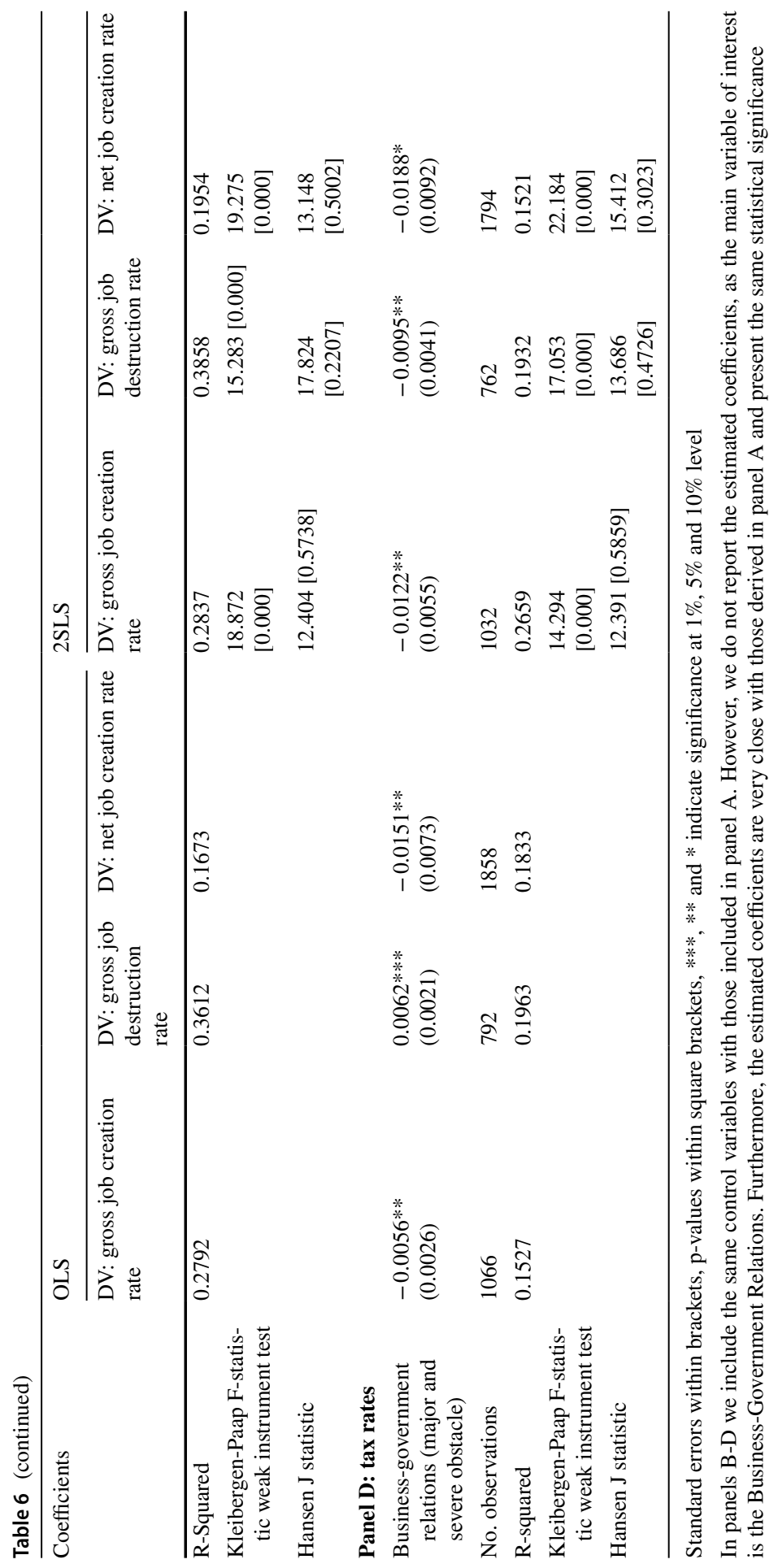


in the informal sector to attract more employment. Earlier studies also support that electricity is a major constraint for the firm growth and therefore an unreliable supply of electricity can have also a significant adverse effect on job creation and growth. orld Bank (2008) finds that expensive, unreliable or unavailable electricity is a major barrier for firms in Kenya. Similarly, firms in Tanzania and Liberia recognize unreliable electricity as a major obstacle to firm operations. Therefore, power outages due to lack of proper infrastructure and also expensive supply of power will have a negative impact on sales and consequently on job creation. Power outages in Tanzania cost firms around 15 percent of annual sales, according to a 2013 survey of 813 firms (Lemma et al. 2016).

For the remained variables in the empirical work, we observe that the results are significantly different compared to those we found in the case of firms in Egypt. In particular, firms in Turkey with female owners and accredited with an international certification of quality present higher gross and net job creation rates, while the relationship between job destruction rates and international certification of quality is negative. While this study has not discussed so far any theoretical framework explaining this positive relationship between female employers and job creation, a survey conducted by EY (2016) among 2,673 entrepreneurs around the globe, reveals some interesting related results. First, it seems that women lead the job creation stakes who report an average growth rate of 10.9 percent in the next year 2017 compared to the 8.3 percent among the male entrepreneurs. Furthermore, the 43 percent of the women stated that they hired more employees than expected in the previous year-2015-compared to the 39 percent of the male entrepreneurs. Another characteristic of the survey's results is that the 56 percent of the female entrepreneurs younger than the age of 35 reported a better job creation rate than the expected in 2015, while the 16 percent expect a 16 percent average increase in the workforce size. The respective values for the men in the same age brackets are 56 and 13 percent (EY 2016).

We observe that the quadratic term of firm size is significant in firms in Egypt, while only the linear term is significant in the case of Turkey. According to Table 5, the linear term of the firm size is positive and significant in job creation and net job creation rates, but negative regarding job destruction rates. The respective signs of the quadratic terms are negative and positive. This illustrates an inverted U-shaped curve for the job creation rates and a U-shaped curve for the job destruction rate, implying that after some point the employment growth rates reduces, while the job destruction rates increase. The turning point for the gross job creation rate using both OLS and 2SLS is around 110 employees. The turning point for the gross job destruction rates is around 30 employees, while for the net job creation rates it becomes roughly 20 employees. A similar concluding remark is observed for the firm age, but the coefficients become insignificant in the net job creation rates regressions. In particular, according to the OLS and 2SLS estimates, firms older than 15-16 years create a fewer number of jobs, and they destroy more jobs compared to the young 
firms. A common finding is that firms accredited with an international quality of certification create more jobs and destroy less jobs in Turkey, while they destroy less jobs in Egypt. ${ }^{2}$

Regarding the validity of our instruments, we need to test whether they are weak or in other words, whether they are good predictors of the endogenous variables, which is the SBRs. Second, we will test whether the instruments are exogenous and uncorrelated with the outcomes-job flows explored. In all cases we reject the null hypothesis of the weak instruments test. In particular, in Tables 5, 6 we report the Kleibergen-Paap F-statistic test from the first stage regression, where we regress each obstacle in SBRs on the instruments discussed earlier and presented in panel $\mathrm{B}$ of Table 1. In line with the evidence and according to the rule of thumb of a value of F-statistic more than 10, we conclude that the instruments employed turn out to be strong predictors of the SBRs. As we observe from Tables 5, 6 in all cases the $F$-statistic of the weak instrument test is higher than 10, except for the gross job creation rate and the net job creation rate regressions for corruption in panel D of Table 5 for Egypt, which are close to 10. Furthermore, the same applies for Turkey when we consider the political instability and panel B of Table 6, where the value of $F$-statistic for the gross job destruction rate and the net job creation rate is respectively 6.5 and 9.1, indicating that the instruments used in the case of the political instability as an indicator of SBR in Turkey, are rather weak. In Tables 5, 6 we report also the Hansen $\mathrm{J}$ over-identification test derived from the 2SLS method. The joint null hypothesis is that the instruments used are valid instruments, implying that are exogenous, uncorrelated with the error term and they have an indirect effect on the outcomes explored through the SBRs variables and thus, are correctly excluded from the estimated regressions. According to the $p$-value associated with the Hansen J test, we accept the null hypothesis in all cases for both Egypt and Turkey and therefore, we conclude that they are valid instruments.

\subsection{Robustness checks}

In this section, we perform a variety of sensitivity and robustness checks. First, we repeat the same estimations with Tables 5 and 6 employing only the panel data set and applying a fixed effects OLS model. Second, we limit the analysis only to SMEs, excluding firms with more than 100 workers. In this case, the sample is ranging between 75-78 percent of the full sample. Third, we will perform a placebo test, which is a falsification exercise to provide evidence on the precision of the identified link between SBRs and job flows.

In Tables 7, 8, we report the estimates using the panel dataset and the sample for SMEs. The main benefit of using the panel data in the first case is that it allows us to control for unobservable time-invariant firm characteristics, such as the profit and efficiency, the entrepreneurial ability of the firm owners and managers, which may

\footnotetext{
${ }^{2}$ We should notice that panels B-D in tables 5-6 we include the same set of control variables as in panel A. However, as the SBRs is the main factor of interest, and since the estimated coefficients of the remained controls remain very similar to those found in panel A, we do not report them.
} 


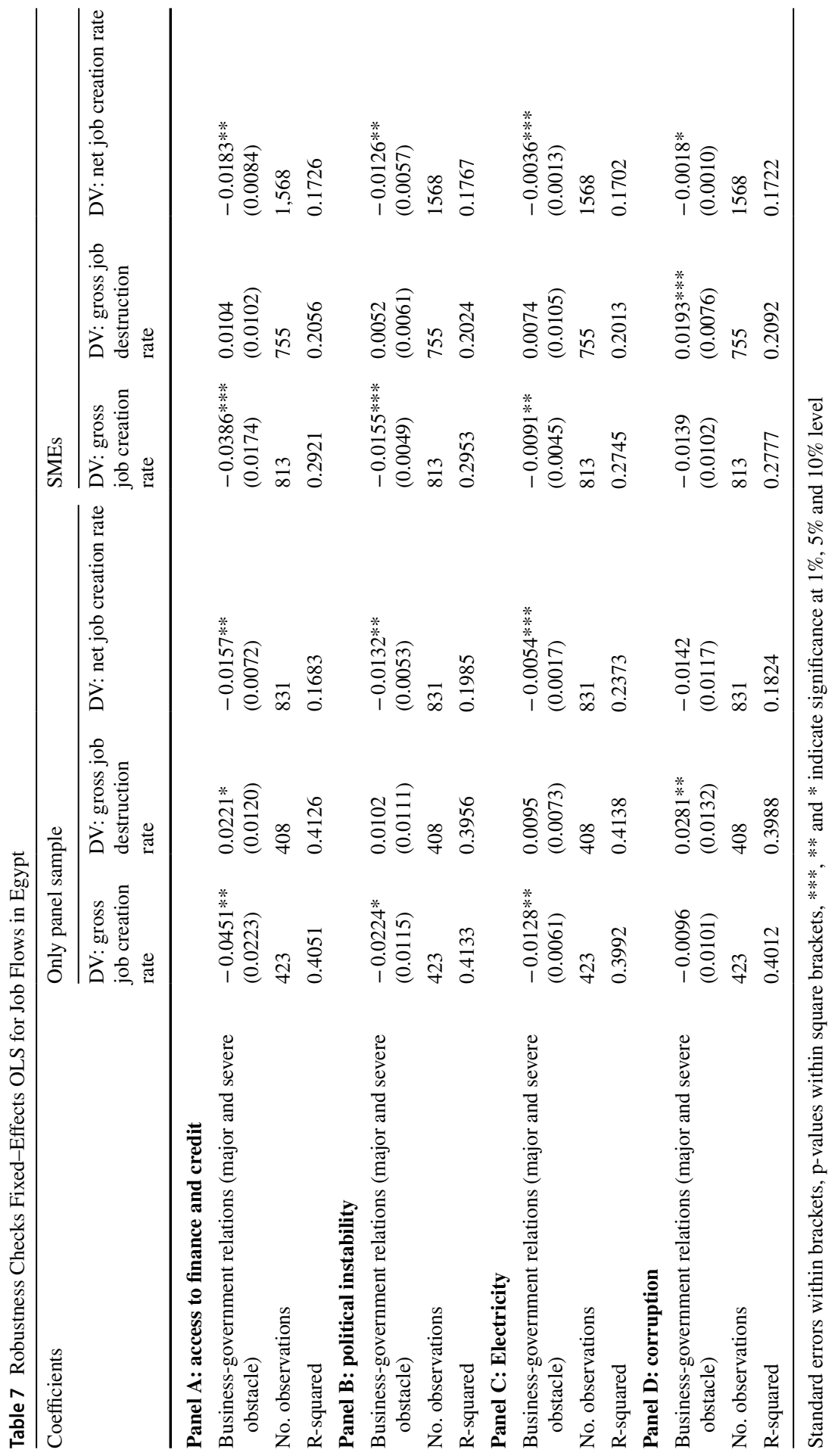




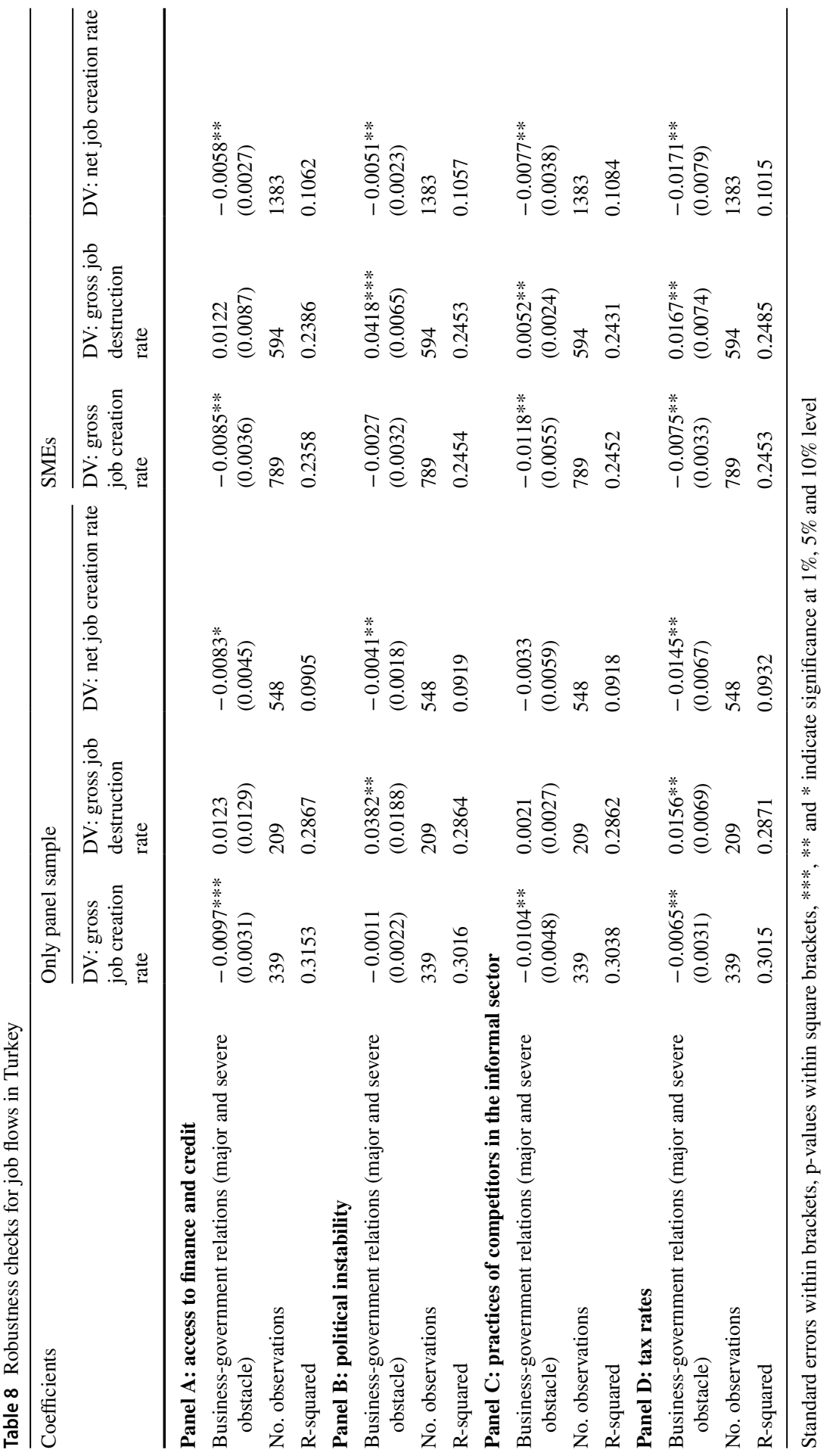


affect the obstacles in SBRs and employment growth. Therefore, the main benefit of the fixed effects OLS estimates is that we may handle the endogeneity of the SBRs measures and also to difference out time-invariant industry, sector and area-location specific factors. Overall, the results based on the panel data are quite similar with those derived by the 2SLS in Tables 5, 6, indicating that fixed effects may reduce endogeneity due to omitted variables bias up to some degree.

Next in the last three columns of Tables 7 and 8, we report the estimates for the SMEs sample, which firms form the backbone of economic activity, not only for the MENA region, but also in other developing regions and for the majority of the developed countries. Nevertheless, SMEs may suffer more from corruption and unfavorable conditions of business environment, implying that policy intervention and reforms should target mainly to the economic growth of SMEs. Furthermore, the sample of SMEs provides us with a more homogeneous group of firms compared to the full sample, where we include also the large firms. More precisely, SMEs consist almost of the 75-78 percent of the full sample, while a few number of firms in our sample report a very high number of employees, reducing in this way the noise in the data. As we mentioned earlier, we limit the sample of firms not exceeding the 100 employees. In this case, we observe that the impact of the obstacles in SBRs is more severe indicating the importance of constraints and limitations small firms face, which includes also young firms. Therefore, the results show that SMEs are more vulnerable in the obstacles in SBRs explored and hence, proper policies targeting the specific group of firms should be encouraged and implemented. Nevertheless, the results are compared with the OLS cross-sectional analysis in Tables 5, 6, but the results can be quite underestimated compared to the 2SLS method.

The last robustness check involves a placebo test; however, based on the data availability and limitations, it is quite difficult to find a proper variable in order to conduct a reliable placebo test. Therefore, exploring policy interventions and reforms that allow us to implement a difference-in-differences (DiD) and a regression discontinuity design (RDD) and compare the pre-period and post-period outcomes, provide a more reliable and robust platform to perform placebo tests.

In our effort to provide evidence of the relationship between SBRs and the jobdestruction rates, we use different variables as proxies to SBRs. In particular, for the access to finance and credit, we use a variable indicating whether the firm has acquired any line of credit or loan over the last fiscal year (Rahman et al. 2018). For electricity, we use the submission of application for electricity supply over the last 2 fiscal years (Geginat and Ramalho 2015). While we argue that these proxies are not the most reliable ones, given the information provided by the World Bank ES, we assume that using the information on whether the firms have already a loan or have submitted for electricity supply should have no effect on the outcomes explored. Furthermore, we limit our analysis only to firms that have reported no obstacles in the SBRs explored, which can be seen by the low number of observations in Table 9. The same applies for the rest of the obstacles in SBRs examined below. For the corruption we replace the SBR with the variable taking value 1 if the financial statements of the establishments are checked and certified by an external auditor over the last fiscal year (Farooq and Shehata 2018), while for tax rates we use the information about the average number of visits by tax officials (Kochanova et al. 2018). For 


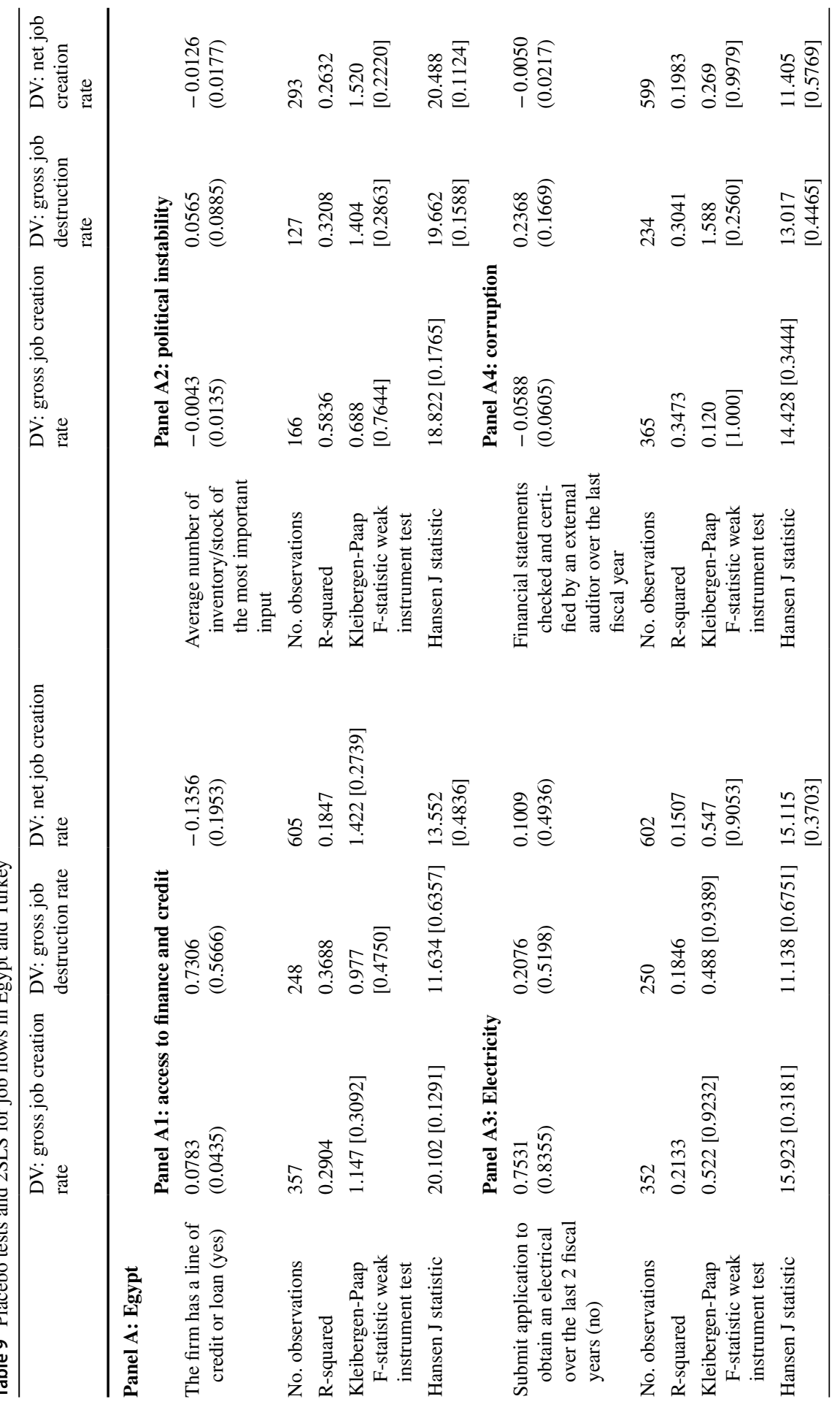




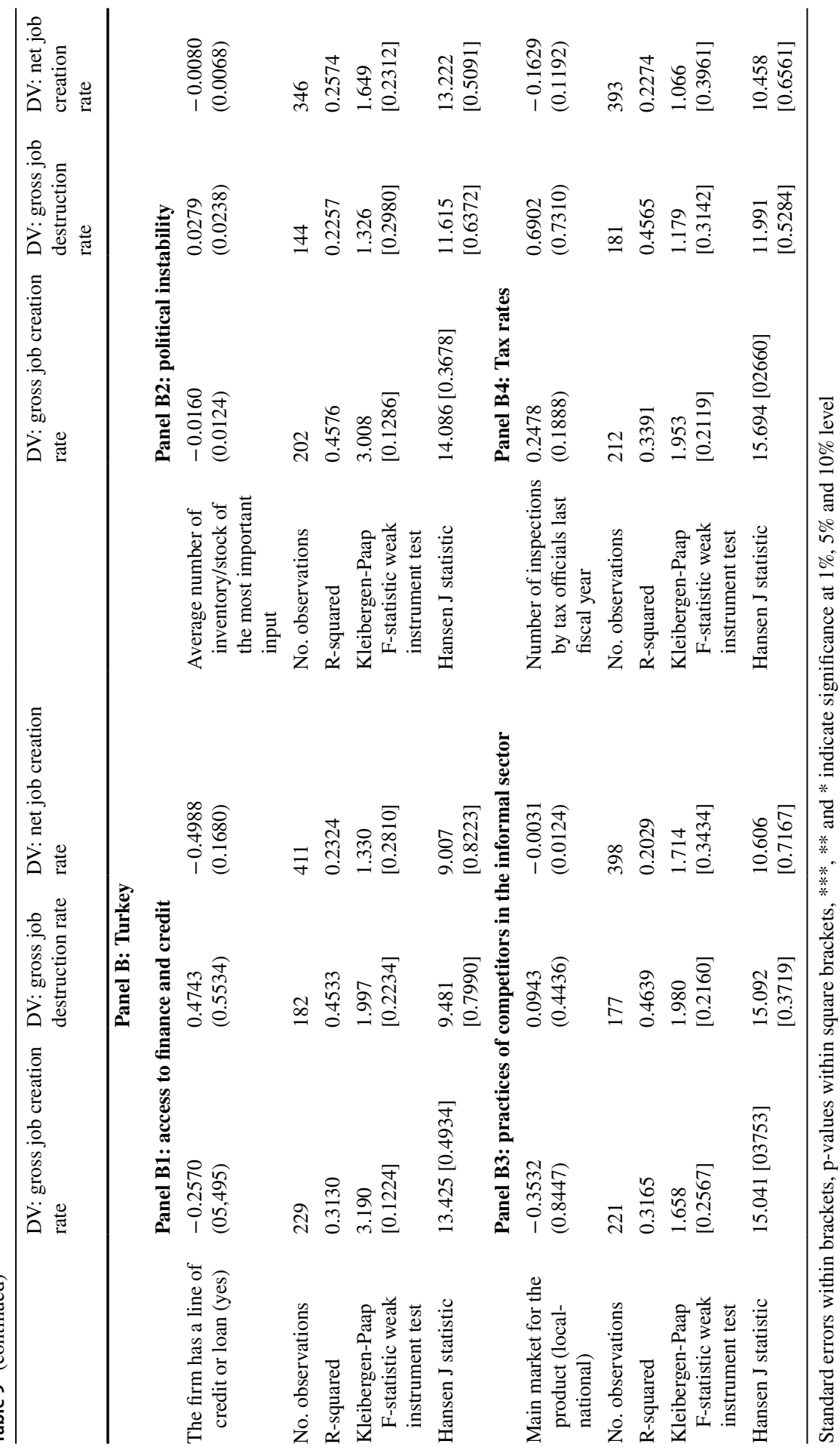


the political instability, we consider the average number of inventory of the most important input, as this shows the degree of vulnerability and resistance on periods of uncertainty and political instability, depending also on the volume of exports and imports (Chawdhury 2016; Grechyna 2017). Nevertheless, this type of SBRs mainly refers to national level, while the remained SBRs explored can be allocated at regional, local or even at firm level. For instance, corruption can be influenced at the individual-firm level, while competition from the informal sector and the quality of electricity supply can be influenced at a local or regional level. Finally, for the competition practices from the informal sector, we replace the main SBR with a dummy indicating whether the firm is functioning only at a local-national level or at an international level (Varcin 2000). The justification of using this variable is that national and even more local firms may face more competition from the informal sector and could be more vulnerable to this type of competition. Therefore, considering these proxies and limiting the sample of analysis to firms reporting no obstacles on SBRs, we should expect an insignificant estimated coefficient and acceptance of the null hypothesis of the weak instrument test. This will imply that the placebo test is valid, providing evidence about the identification of the link between SBRs and the job creation-destruction rates. In all cases, we observe that the estimated coefficients are insignificant, while we fail to reject the null hypothesis of the weak instrument test according to the Kleibergen-Paap F-statistic and the associated $p$-values. Exception is the gross job destruction rate in Egypt and the access to finance and credit. Moreover, based on the Hansen J test, we fail to accept the null hypothesis. Furthermore, the correlation between those proxies and the SBRs is significant, but we do not present the results. ${ }^{3}$

\section{Discussion and conclusions}

This study investigated the determinants of job flows in Egypt and Turkey and the impact of SBRs on job flows. Effective SBRs and a supportive business environment is vital for the firm performance, innovation and job creation. The main concluding remark is that the impact of firm size and age on employment growth differs in both economies, while obstacles in the state-business relations have a negative and significant impact on the net job creation rates. Understanding the factors and obstacles hampering private firms' growth and innovation and addressing the constraints through policy reforms are the main priorities for policy makers. The findings suggest a negative impact of the obstacles in effective SBRs in both economies explored and access to finance and credit and political instability are the two main common obstacles in Egypt and Turkey. Furthermore, we found a positive relationship between the job creation and various determinants in Turkey, including female ownership and the accreditation of an international certification of quality, which can be explained by the large proportion of firms reported in Table 4. On the other

\footnotetext{
3 Overall, we conclude that the placebo tests are valid and the variables used as proxies to the main SBRs explored are proper, confirming the link between SBRs and job growth rates and the robustness of our estimates in Tables 5-6.
} 
hand, in Egypt and Turkey, we find that labor productivity is positively related with the job creation, while the firms in the services sector create less jobs compared to firms in the manufacturing sector.

While our main aim of the study was to illustrate the job flows, and their relationship with various firm characteristics, the study could have been expanded by exploring also reforms and their impact on the productivity and job creation, which can improve also the robustness of the placebo tests performed in the study. Nevertheless, we suggest for future studies the investigation of various reforms, such as employment, subsidies to specific industries and regions, and the evaluation of their impact on the above-mentioned outcomes.

However, the analysis is not without drawbacks. First, the sample of the firms and the period examined, and specifically the waves, is very short. Second, another major drawback in our opinion is the quality of the jobs created. In particular, the analysis should be concentrated not only on the quantity of the jobs created, but also on the quality, in terms of skills acquired, future perspectives and wage levels. More skilled job may lead also to higher economic growth, through higher productivity and thus, to a further economic expansion and employment growth. Moreover, if the job creation in the countries explored, including also other developing economies in the MENA region and around the globe, takes place mainly in traditional sectors and not in technological start-ups or high productive firms, these economies will lag behind other countries in terms of efficiency, productivity and economic growth, and hence, in employment growth in the long run period.

Previous studies show that banking and financial markets in the MENA region are less competitive compared to other regions in the world, which is due to lack of market contestability and poor knowledge of the financial and credit environment (Murjan and Ruza 2002; Al-Muharrami et al. 2006; Anzoategui et al. 2010). A large proportion of the firms in the private sector does not have access to credit and banking system and it is unbundled with the financial sector, undermining the prospects of growth. Lower government funding requirements and increase in the banking competition are likely to have a positive effect on access to finance and credit. Credit risk management capacity building initiatives of banks should be followed by a shift and reform in the regulatory posture towards increased competition. In particular, improvement in access to finance should not come at the expense of financial stability, but the regulatory structure must be adjusted to prevent competition from contributing to risky lending practices (Keeley 1990; Beck et al. 2013). Governments and donors should support measures to develop and enhance the screening of banks' capacity and to increase the supply of bankable firms. This type of activities would seek to make SMEs less opaque, reducing information asymmetries and helping firms to create a business plan or build an organizational structure in action. However, those services are limited, because they are typically small in comparison to the size of the economy (McKenzie 2015). Increasing competition may provide incentives and opportunities to banks to find new market segments, including lending to SMEs.

The second major common obstacle in SBRs in both countries examined is political instability, while corruption, electricity for Egypt and tax rates and competition from the informal sector in Turkey are other major obstacles. The 
consequences of political instability go beyond the apparent intervention of armed and political turmoil. It has to be seen as creating a general environment of economic policy and regulatory stability which can cross national borders. Policies to minimize corruption in the region must look further than small-scale corruption and at the wider public-private-interactive institutional climate. Such a general view of corruption as a burden and a failure to engage the state can have large consequences. Moreover, the relationship among the SBRs we explored can be self-reinforcing. More specifically, insufficient supply of utilities, such as electricity can create widespread resentment, while political instability and turmoil can undermine infrastructure through lack of investments and violent conflicts. Reform strategies should improve the energy sector efficiency, including elimination of political instability, corruption, competition practices from the informal sector, distorting taxes and also subsidies, as these can lead to an inefficient use of resources.

Thus, a more in-depth investigation and analysis of determinants and reforms that affect the job creation rate, productivity and firm performance is important in future studies. State-business relations can be also important factors. For instance, labor and trade regulations may hinder the job creation rates, so flexible labor markets could be more desirable. However, the reforms should encourage investment and job creation, but also the policy challenges include improvement of the worker protection. This is also in line with the fact that the countries we explored in this study have an extensive informal economy, where a large proportion of the workers is not registered in the social security institutions and therefore, do not enjoy the protections associated with those systems. Additionally, even though we control for region, industry and sector, more insightful concluding remarks can be derived if a more in-depth analysis takes place within those groups. Many more cases and obstacles can be discussed, but the main point is that state-business relations, among the other factors we explored, may determine the job creation and employment growth.

Acknowledgements This paper was presented at the Workshop on "Structural Change, Resource Misallocation and Growth Dynamics in the MENA Region" at Luxor, Egypt on 28 February-1 March funded and organized by ERF. The authors would like to thank Dr. Jorge Rodriguez Meza, Program Manager of the Enterprise Analysis Unit at the World Bank and Dr. David Francis analyst at the Enterprise Analysis Unit for their valuable comments. The authors would like to thank the anonymous reviewers for their valuable comments, suggestions and constructive comments that greatly contributed to the improvement of the quality of this paper. Any remaining errors or omissions remain the responsibility of the authors.

Funding The authors gratefully acknowledge financial support from the Economic Research Forum (ERF) and the grant received under the "Structural Change, Resource Misallocation and Growth Dynamics in the MENA Region" program call. An earlier version of this study is published as a working paper under the funding agreement with the Economic Research Forum (ERF) available at https://erf.org.eg/ publications/state-business-relations-and-the-dynamics-of-job-flows-in-egypt-and-turkey/.

\section{Compliance with ethical standards}

Conflict of interest The authors declare that have no conflict of interest.

Ethical approval This article does not contain any studies with human participants or animals performed by the author. 
Open Access This article is licensed under a Creative Commons Attribution 4.0 International License, which permits use, sharing, adaptation, distribution and reproduction in any medium or format, as long as you give appropriate credit to the original author(s) and the source, provide a link to the Creative Commons licence, and indicate if changes were made. The images or other third party material in this article are included in the article's Creative Commons licence, unless indicated otherwise in a credit line to the material. If material is not included in the article's Creative Commons licence and your intended use is not permitted by statutory regulation or exceeds the permitted use, you will need to obtain permission directly from the copyright holder. To view a copy of this licence, visit http://creativecommons.org/licen ses/by/4.0/.

\section{References}

Adly, A. I. (2009). Politically-embedded cronyism: The case of Post-Liberalization Egypt. Business and Politics, 11(4), 1-26.

Aga, G., Francis, D.C., \& Meza, J.R. (2015). SMEs, age, and jobs: A review of the literature, metrics, and evidence. World BankPolicy Research Working Paper 7493. Development Economics, Global Indicators Group.

Al-Muharrami, S., Matthews, K., \& Khabari, Y. (2006). Market structure and competitive conditions in the Arab GCC banking system. Journal of Banking and Finance, 30, 3487-3501.

Amin, M., Bending, T., Francis, D.C., Islam, A.M., Jain, A., \& Meza, J.R. (2016). Firm productivity and the business environment in de Lima, P. Revoltella, D., Meza, J.R., \& Schweiger, H. (Eds ) What's Holding Back the Private Sector in MENA? Lessons from the Enterprise Survey Chapter 2, pp. 15-34, World Bank.

Ansell, C., \& Gash, A. (2007). Collaborative governance in theory and practice. Journal of Public Administration Research and Theory, 18(4), 543-571.

Anzoategui, D., Peria, M. S. M., \& Rocha, R. (2010). Bank competition in the middle East and North Africa. Review of Middle East Economics and Finance, 6(2), 2.

Arouri, H., Youssef, A. B., \& Quatraro, F. (2016). Entry, exit and net job creation in Tunisia: An exploratory analysis. Eurasian Business Review, 6(3), 323-337.

Aterido, R., Hallward-Driemeier, M., \& Pagés, C. (2011). Big constraints to small firms' growth? Business environment and employment growth across firms. Economic Development and Cultural Change, 59(3), 609-647.

Baldwin, J., \& Yan, B. (2011). The death of Canadian manufacturing plants: Heterogeneous responses to changes in tariffs and real exchange rates. Review of World Economics, 147(1), 131-167.

Bartelsman, E. J., Falk, M., Hagsten, E., \& Polder, M. (2019). Productivity, technological innovations and broadband connectivity: Firm-level evidence for ten European countries. Eurasian Business Review, 9(1), 25-48.

Beck, T., De Jonghe, O., \& Schepens, G. (2013). Bank Competition and Stability: Cross-country heterogeneity. Journal of Financial Intermediation, 22(2), 2018-2244.

Beck, T., \& Demirguc-Kunt, A. (2006). Small and medium-size enterprises: Access to finance as a growth constraint. Journal of Banking and Finance, 30, 2931-2943.

Beck, T., Demirguc-Kunt, A., \& Levine, R. (2005a). SMEs, growth, and poverty: Cross-country evidence. Journal of Economic Growth, 10, 199-229.

Beck, T., Demirguc-Kunt, A., \& Maksimovic, V. (2005b). Financial and legal constraints to growth: Does firm size matter? The Journal of Finance, 60(1), 137-177.

Bernard, A., \& Sjöholm, F. (2003). Foreign owners and plant survival. NBER Working Papers 10039.

Carlin, W., Schaffer, M., \& Seabright, P. (2006). Where are the real bottle necks? A Lagrangian approach to identifying constraints on growth from subjective data, CERT discussion paper 2006/04. Centre for Economic Reform and Transformation, School of Management and Languages, Heriot-Watt University, Edinburgh.

Chawdhury, J. (2016). Political instability: A major obstacle to economic growth in Bangladesh. Thesis. CENTRIA University of Applied Sciences. Business Management.

Cojocaru, A. (2012). Essays on Inequality, Social Mobility, and Redistributive Preferences in the Transition Economies. PhD Dissertation, School of Public Policy, University of Maryland, May. 
Collins, J. D., Uhlenbruck, K., \& Rodriguez, P. (2009). Why firms engage in corruption: A top management perspective. Journal of Business Ethics, 87(1), 89-108.

Commander, S., \& Svejnar, J. (2007). Do institutions, ownership, exporting and competition explain firm performance? Evidence from 26 Transition Countries. IZA Discussion Paper No. 2637, Bonn, Germany.

Corbett, C. J., Montes, M. J., Kirsch, D. A., \& Alvarez-Gil, M. J. (2002). Does ISO 9000 certification pay? ISO Management Systems Special Report, 2(4), 31-40.

Cravo, T., Jacinto, P., \& Schimanski, C. (2018). Employment cyclicality by firm size, wage and productivity in Brazil. IDB Publications, Working Papers, No. 9246, Inter-American Development Bank.

Croson, R., \& Gneezy, U. (2009). Gender differences in preferences. Journal of Economic Literature, 47(2), 448-474.

Davis, S. J., \& Haltiwanger, J. (1990). Gross Job Creation and Destruction: Microeconomic Evidence and Macroeconomic Implications. NBER Chapters, in: NBER Macroeconomics Annual 1990, Volume 5, 123-186.

Davis, S. J., \& Haltiwanger, J. (1992). Gross job creation, gross job destruction, and employment reallocation. The Quarterly Journal of Economics, 107(3), 819-863.

Davis, S. J., \& Haltiwanger, J. (1999). Gross job flows. Handbook of Labor Economics, in: O. Ashenfelter and D. Card (ed.), Handbook of Labor Economics, 1(3), chapter 41, 2711-2805.

Davis, S.J., Haltiwanger, J., \& Schuh, S. (1993). Small Business and Job Creation: Dissecting the Myth and Reassessing the Facts. Working Paper No. 4492, NBER Working Paper Series.

Davis, S. J., Haltiwanger, J., \& Schuh, S. (1998). Job Creation and Destruction. The MIT Press: MIT Press Books.

Decker, R., Haltiwanger, J., Jarmin, R., \& Miranda, J. (2014). The role of entrepreneurship in US job creation and economic dynamism. Journal of Economic Perspectives, 28(3), 3-24.

Dethier, J.-J., Hirn, M., \& Straub, S. (2010). Explaining enterprise performance in developing countries with business climate survey data. The World Bank Research Observer, 26(4792), 258-309.

Dollar, D., Hallward-Driemeier, M., \& Mengistae, T. (2003). Investment climate and firm performance in developing economies. Unpublished manuscript, World Bank.

Dollar, D., Hallward-Driemeier, M., \& Mengistae, T. (2005). Investment climate and firm performance in developing economies. Economic Development and Cultural Change, 54(1), 1-31.

Dollar, D., Hallward-Driemeier, M., \& Mengistae, T. (2006). Investment climate and international integration. World Development, 34(9), 1498-1516.

Doner, R. F., \& Schneider, M. R. (2000). Business associations and economic development: Why some associations contribute more than others. Business and Politics, 2(3), 261-288.

Dunne, T., Roberts, M. J., \& Samuelson, L. (1989). Plant turnover and gross employment flows in the U.S. manufacturings sector. Journal of Labor Economics, 7(1), 48-71.

Elgin, C., \& Erturk, F. (2019). Informal economies around the world: Measures, determinants and consequences. Eurasian Economic Review, 9(2), 221-237.

Escribano, A., Guasch, J.L. (2005). Assessing the impact of the business climate on productivity using firm level data: Methodology and the cases of Guatemala, Honduras, and Nicaragua. World Bank Policy Research Working Paper 3621.

Evans, D. S. (1987a). The relationship between firm growth, size and age: Estimates for 100 manufacturing industries. The Journal of Industrial Economics, 35, 567-581.

Evans, D. S. (1987b). Tests of alternative theories of firm growth. Journal of Political Economy, 95, 657-674.

Evans, P. B. (2012). Embedded autonomy: States and industrial transformation. Princeton: Princeton University Press.

EY (2016). Does disruption drive job creation? EY Global Job Creation Survey 2016.

Faccio, M., Marchica, M. T., \& Mura, R. (2016). CEO gender and corporate risk-taking. Journal of Corporate Finance, 39, 193-209.

Fajnzylber, P., Maloney, W. F., \& Montes-Rojas, G. V. (2009). Releasing constraints to growth or pushing on a string? Policies and performance of Mexican micro-firms. Journal of Development Studies, 45(7), 1027-1047.

Farooq, O., \& Shehata, N. F. (2018). Does external auditing combat corruption? Evidence from private firms. Managerial Auditing Journal, 33(3), 267-287. 
Ferraz, C., Finan, F., \& Szerman, D. (2015). Procuring firm growth: the effects of government purchases on firm dynamics, Working Paper No. 21219. National Bureau of Economic Research.

Fisman, R., \& Svensson, J. (2007). Are corruption and taxation really harmful to growth? Firm level evidence. Journal of Development Economics, 83, 63-75.

Fort, T. C., Haltiwanger, J., Jarmin, R. S., \& Miranda, J. (2013). How firms respond to business cycles: The role of firm age and firm size. IMF Economic Review, 61(3), 520-559.

Geginat, C., \& Ramalho., R. (2015). Electricity connections and firm performance in 183 countries. The World Bank Working Paper Series No. 7460. Development Economics, Global Indicators Group.

Gelübcke, J., \& Wagner, J. (2012). Foreign ownership and firm survival: First evidence for enterprises in Germany. Economie Internationale, 132, 117-139.

Gertler, M., \& Gilchrist, S. (1994). Monetary policy, business cycles, and the behavior of small manufacturing firms. The Quarterly Journal of Economics, 109(2), 309-340.

Gibrat, R. (1931). Les inegalites economiques; aux inegalite's des richesses, a la concentration des entreprises, aux populations des villes, aux statistiques des familles, etc., d'une loi nouvelle, la loi de l'effet proportionnel, Librairie du Recueil Sirey.

Giovanis, E., \& Ozdamar, O. (2018a). Productivity and resource misallocation: evidence from firms in Middle East and North Africa (MENA) Region countries. In The Economic Research Forum (ERF) Working Paper, No. 1266, Cairo, Egypt.

Giovanis, E., \& Ozdamar, O. (2018b). State business relations and the dynamics of job flows in Egypt and Turkey. In The Economic Research Forum (ERF), Working Paper No. 1271, Cairo, Egypt.

Giovanis, E., \& Ozdamar, O. (2018b). The nexus between business-investment climate and firm performance in the Middle East and North Africa (MENA) region. In The Economic Research Forum (ERF) Working Paper (No. 1277), Cairo, Egypt.

Goedhuys, M., Mohnen, P., \& Taha, T. (2016). Corruption, innovation and firm growth: Firm-level evidence from Egypt and Tunisia. Eurasian Business Review, 6(3), 299-322.

Goedhuys, M., \& Sleuwaegen, L. (2010). High-growth entrepreneurial firms in Africa: A quantile regression approach. Small Business Economics, 34(1), 31-51.

Grechyna, D., (2017). Trade openness and political distortions. Available at SSRN 2965028.

Hallak, I., \& Harasztosi, P. (2019). Job Creation in Europe: A firm-level analysis. Luxembourg: Joint Research Centre Science for Policy Report European Commission.

Haltiwanger, J. C., Hyatt, H. R., Kahn, L. B., \& McEntarfer, E. (2018). Cyclical job ladders by firm size and firm wage. American Economic Journal Macroeconomics, 10(2), 52-85.

Haltiwanger, J., Jarmin, R. S., \& Miranda, J. (2013). Who creates jobs? Small versus large versus young. The Review of Economics and Statistics, 95(2), 347-361.

Hansen, H., Rand, J., \& Tarp, F. (2009). Enterprise growth and survival in Vietnam: Does government support matter? Journal of Development Studies, 45(7), 1048-1069.

Hausmann, R., \& Rodrik, D. (2003). Economic development as self- discovery. Journal of Development Economics, 72(2), 603-633.

Hawash, R., \& Lang, G. (2020). Does the digital gap matter? Estimating the impact of ICT on productivity in developing countries. Eurasian Economic Review, 10(2), 189-209.

Hijzen, A., Upward, R., \& Wright, P. W. (2010). Job creation, job destruction and the role of small firms: Firm-level evidence for the UK. Oxford Bulletin of Economics and Statistics, 72(5), 621-647.

Jovanovic, B. (1982). Selection and the evolution of industry. Econometrica, 50(3), 649-670.

Kazuya, O. (2009). Long working hours in Japan: An international comparison and research topics. Japanese Economy, 36(2), 23-45.

Keeley, M. (1990). Deposit insurance, risk, and market power in banking. American Economic Review, $80(5), 1183-1200$.

Kien, N. T. (2015). Manufacturing exports and employment generation in Vietnam. Southeast Asian Journal of Economics, 3(2), 1-21.

Klapper, L., Laeven, L., \& Rajan, R. (2006). Barriers to entrepreneurship. Journal of Financial Economics, 82(3), 591-629.

Knack, S., \& Keefer, P. (1995). Institutions and economic performance: Cross-country tests using alternative measures'. Economics and Politics, 7(3), 207-227.

Kochanova, A., Hasnain, Z., \& Larson, B. (2018). Does e-government improve government capacity? Evidence from tax compliance costs, tax revenue, and public procurement competitiveness. The World Bank Economic Review. https://doi.org/10.1093/wber/lhx024. 
Kormendi, R., \& Meguire, P. (1985). Macroeconomic determinants of growth: CrossCountry evidence. Journal of Monetary Economics, 16(2), 141-163.

Lafuente, E., Bayo-Moriones, A., \& García-Cestona, M. (2010). ISO-9000 certification and ownership structure: Effects upon firm performance. British Journal of Management, 21, 649-665.

Lawless, M. (2014). Age or size? Contributions to job creation. Small Business Economics, 42(4), $815-830$.

Leftwich, A. (2009). Analysing the Politics of State-Business Relations: A Methodological Note on the Historical Institutionalist Approach, IPPG Discussion Paper Series 23. Manchester: IPPG.

Lemma, A., Massa, I., Scott, A., \& te Velde, A.W. (2016). What are the links between power, economic growth and job creation? Development Impact Evaluation, Evidence Review, Overseas Development Institute.

Lotti, F., Santarelli, E., \& Vivarelli, M. (2003). Does Gibrat's law hold among young, small firms? Journal of Evolutionary Economics, 13, 213-235.

Maxfield, S., \& Schnneider, B. R. (1997). Business, the state and economic performance in developing countries. In R. Schneider \& S. Maxfield (Eds.), Business and the State in Developing Countries B (pp. 3-36). Ithaca: Cornell University Press.

Mazumdar, S. (2008). Crony capitalism: Caricature or category? Institute for Studies in Industrial Development, Working Paper 02, New Delhi, India.

McArthur, J., \& Teal, F. (2002). Corruption and firm performance in Africa. Working Paper No. 200210, Centre for the Study of African Economies, Department of Economics, University of Oxford.

McKenzie, D.J. (2015). Identifying and spurring high-growth entrepreneurship: experimental evidence from a business plan competition. Policy Research working paperNno. WPS 7391. Impact Evaluation series. Washington, D.C.: World Bank Group.

Moscarini, G., \& Postel-Vinay, F. (2012). The contribution of large and small employers to job creation in times of high and low unemployment. American Economic Review, 102(6), 2509-2539.

Moscarini, G., \& Postel-Vinay, F. (2016). Did the job ladder fail after the Great Recession? Journal of Labor Economics, 34(S1), S55-S93.

Murjan, W., \& Ruza, C. (2002). The competitive nature of the Arab Middle Eastern banking markets. International Advances in Economic Research, 4(8), 267-274.

Naveh, E., \& Marcus, A. (2005). Achieving competitive advantage through implementing a replicable management standard: Installing and using ISO 9000. Journal of Operations Management, 24, $1-26$.

Qureshi, M. S., \& Te Velde, W. D. (2013). State-business relations, investment climate reform and firm productivity in Sub-Saharan Africa. Journal of International Development, 25(7), 912-935.

Rahman, A., Rozsa, Z., \& Cepel, M. (2018). Trade credit and bank finance-evidence from the visegrad group. Journal of Competitiveness, 10(3), 132-148.

Rodrik, D., Subramanian, A., \& Trebbi, F. (2004). Institutions rule: The primacy of institutions over geography and integration in economic development. Journal of Economic Growth, 9(2), 131-165.

Sabry, M. I. (2019). State business relations and economic growth prospects in post-arab spring MENA. Available at SSRN 3359866. https://papers.ssrn.com/sol3/papers.cfm?abstract_id=3359866.

Şeker, M. (2011). Rigidities in employment protection and exporting. World Development, 40(2), $238-250$.

Şeker, M., \& Correa, P. G. (2010). Obstacles to growth for small and medium enterprisesin Turkey. Working Paper Series No. 5323.

Şeker, M., \& Yang, J. S. (2014). Bribery solicitations and firm performance in the Latin America and Caribbean region. Journal of Comparative Economics, 42, 246-264.

Sen, K., \& Te Velde, D. W. (2009). State business relations and economic growth in Sub-Saharan Africa. Journal of Development Studies, 45(8), 1267-1283.

Sharpe, S. (1994). Financial market imperfections, firm leverage, and the cyclicality of employment. American Economic Review, 84(4), 1060-1074.

Stone, A., Badawy, L., \& Assaf, N. (2012). The plight of Yemeni private enterprises since the 2011 crisis: a rapid assessment. MENA Knowledge and Learning, Quick Note Series No. 72, World Bank, Washington, DC.

Subramanian, U., Anderson, W.P., \& Lee, K. (2005). Measuring the impact of the investment climate on total factor productivity: The cases of China and Brazil. Policy Research Working Paper No. 3792, World Bank.

Ullah, B., Wei, Z., \& Xie, F. (2014). ISO certification, financial constraints, and firm performance in Latin American and Caribbean countries. Global Finance Journal, 25, 203-228. 
Varcin, R. (2000). Competition in the informal sector of the economy: The case of market traders in Turkey. International Journal of Sociology and Social Policy, 20(3/4), 5-33.

Vu, H. V., Holmes, M., Tran, T. Q., \& Lim, S. (2016). Firm exporting and productivity: What if productivity is no longer a black box. Baltic Journal of Economics, 16(2), 95-113.

Vu, H., Lim, S., Holmes, M., \& Doan, T. (2013). Firm exporting and employee benefits: First evidence from Vietnam manufacturing SMEs. Economics Bulletin, 33(1), 519-535.

World Bank (2008). Kenya: Accelerating and sustaining inclusive growth. Report No. 42844-KE, Washington DC.

World Bank (2013). World Bank supports boosting much needed electricity generation capacity across Egypt. World Bank, Washington, DC. Available at: https://www.worldbank.org/en/news/press -release/2013/06/27/world-bank-supports-boosting-much-needed-electricity-generation-capacityacross-egypt.

World Bank (2014). Arab republic of egypt more jobs, better jobs: A priority for Egypt. Report No. 88447-EG. Poverty Reduction and Economic Management Department Middle East and North Africa Region.

Wu, H. X. (2013). Measuring industry level employment, output and labour productivity in the Chinese Economy, 1987-2008. Economic Review, 64(1), 42-61.

Publisher's Note Springer Nature remains neutral with regard to jurisdictional claims in published maps and institutional affiliations.

\section{Affiliations}

\section{Oznur Ozdamar $^{1}$ - Eleftherios Giovanis ${ }^{2}$ (D) Sahizer Samuk ${ }^{3}$}

Eleftherios Giovanis

giovanis95@gmail.com; L.giovanis@mmu.ac.uk

Sahizer Samuk

sahsamuk@gmail.com

1 Department of Economics, Izmir University of Bakırçay, Gazi Mustafa Kemal District, Kaynaklar Road, Menemen, 35665 İzmir, Turkey

2 Department of Economics, Policy and International Business (EPIB), Business School, Manchester Metropolitan University, Oxford Road, All Saints Campus, Manchester M15 6BH, UK

3 The Institute of Geography and Spatial Planning, University of Luxembourg, Luxembourg, Luxembourg 